\title{
Defining the Other: An Intellectual History of Sanskrit Lexicons and Grammars of Persian
}

\author{
Audrey Truschke
}

Published online: 20 November 2012

(C) Springer Science+Business Media B.V. 2012

\begin{abstract}
From the fourteenth to the eighteenth centuries, Indian intellectuals produced numerous Sanskrit-Persian bilingual lexicons and Sanskrit grammatical accounts of Persian. However, these language analyses have been largely unexplored in modern scholarship. Select works have occasionally been noticed, but the majority of such texts languish unpublished. Furthermore, these works remain untheorized as a sustained, in-depth response on the part of India's traditional elite to tremendous political and cultural changes. These bilingual grammars and lexicons are one of the few direct, written ways that Sanskrit intellectuals attempted to make sense of Indo-Persian culture in premodern and early modern India. Here I provide the most comprehensive account to date of the texts that constitute this analytical tradition according to three major categories: general lexicons, full grammars, and specialized glossaries. I further draw out the insights offered by these materials into how early modern thinkers used language analysis to try to understand the growth of Persian on the subcontinent.
\end{abstract}

Keywords Sanskrit · Persian · Grammars · Lexicons · Mughal · Intellectual history

\section{Introduction}

She adorns the entire world and

fervently runs towards the glorious king,

\footnotetext{
A. Truschke $(\bowtie)$

Gonville and Caius College, University of Cambridge,

Trinity Street, Cambridge CB2 1TA, UK

e-mail: audrey.truschke@gmail.com
} 
who is a portion of the divine here.

May that radiant speech grant me happiness! ${ }^{1}$

From the fourteenth to the eighteenth centuries, Indian intellectuals produced numerous Sanskrit-Persian bilingual lexicons and grammars of Persian in Sanskrit. These works, more than a dozen in all, span four centuries, were authored by individuals from diverse social communities, and circulated throughout the subcontinent. This extensive body of materials allows unique insight into how early modern thinkers tried to understand the growth of Indo-Persian through the analysis of language, which had long stood at the center of Sanskrit discourse. However, these lexicons and grammars have been largely unacknowledged in modern scholarship. Select works have occasionally been noticed, but the majority of texts languish unpublished. Scarcity of manuscripts has hampered the few who have attempted to seriously investigate these materials. ${ }^{2}$ Furthermore, these works remain untheorized as a sustained, in-depth response on the part of India's traditional elite to tremendous political and cultural changes. Here I provide the most comprehensive account to date of the texts that constitute this analytical tradition and explicate their contexts and implications.

Sanskrit-language analyses of Persian are a noteworthy set of materials in large part because they are one of the few direct, written ways that Sanskrit intellectuals responded to the spread of Indo-Persian culture in premodern and early modern India. Islamicate dynasties flourished on the subcontinent from the twelfth century onwards, and nearly all supported Persian intellectual production. The dual rise of Perso-Islamic power and culture was the single biggest social shift in Indian history up until that point. But, despite coexisting on the subcontinent for centuries, Indian literati were often highly reticent to engage with Persianate or Islamicate traditions within the framework of Sanskrit thought. The classical philosophical tradition never discusses Islam. Except for a few anomalous cases that prove the rule, there was also no open Sanskrit recognition of the Persian literary tradition. ${ }^{3}$ Nonetheless, in select genres, intellectuals freely explored the dynamic possibilities of pairing Sanskrit and Persian knowledge systems. Scholars have drawn substantial attention to cross-cultural trends within astrological and astronomical sciences. ${ }^{4}$ Less well known is that lexicographers and grammarians attempted to investigate Persian in Sanskrit, in their case drawing on sophisticated methods of language analysis. ${ }^{5}$

\footnotetext{
1 yā vibhūṣayati viśvam aśeșam / yatnato narapatim śuciveșam // devatāmśam iha sābhibhajantī / śarma me diśatu vāg vilasantī (Śabdavilāsa, v. 2. Ms. Ahmedabad LD Institute 8311, fol. 1a (reads vo in place of $m e$ ) and quoted in Shah 1972, p. 31). All translations are my own unless otherwise noted.

2 Most recently, Sarma (1996, 2009, forthcoming) has analyzed many of these texts, and I draw upon his work here.

3 A notable exception is a Sanskrit translation of Jāmī’s Yusuf va Zuleykhah, titled Kathākautuka, which was produced by Śrīvara in fifteenth-century Kashmir (printed by Nirnaya Sagar press in 1901). Also, Sheldon Pollock has suggested unacknowledged Indo-Persian influences in the seventeenth-century Sanskrit poetry of Jagannātha Paṇditarāja (2001, pp. 408-411).

4 E.g., David Pingree's work (for an overview, see 1997, pp. 79-90). Also see S.R. Sarma's numerous publications (most recently, 2011).

5 On early Sanskrit grammars of Prakrit, see Pollock (2006, pp. 101-102). Also see Nitti-Dolci (1938).
} 
These bilingual dictionaries and grammars constitute a notably long-lived and diffuse phenomenon. The texts I detail below bridge at least four hundred years (1365-1764), and some remain undated. They were authored by both Brahmans and Jains who hailed from regions across north and central India, including Gujarat, Bengal, and Maharashtra. Moreover, the works circulated throughout the subcontinent with manuscripts moving as far afield as Nepal. ${ }^{6}$ Their contents and production contexts also varied considerably, although many authors had ties with Islamicate rulers. Sanskrit lexicons and grammars of Persian cannot be circumscribed within a single time or place but rather comprise one of the prevailing modes through which Indian intellectuals repeatedly addressed the expansion of Persian language and culture on the subcontinent. We have little evidence regarding the extent to which individual authors were aware of each other's works, and they often conceptualized their projects in dissimilar ways. Nonetheless, these texts form a continuous tradition of intellectual responses on the part of those formed in the Sanskrit thought world to the political, social, and cultural changes associated with the rise of Indo-Persian polities.

Sanskrit literati penned three types of language analyses of Persian: general lexicons, full grammars, and specialized glossaries. The general lexicons pair synonyms of common words in both languages, usually in metered verse. The verses are typically grouped by subject on the model of Amarakośa (Amara's Dictionary), an exceedingly popular Sanskrit thesaurus from the first millennium (ca. fifth century?). ${ }^{7}$ The grammars explain the Persian linguistic apparatus, including case markers, verb conjugation, and syntax and also generally contain basic word lists. Last, the specialized glossaries provide synonymous terms relevant to a particular knowledge system, such as astrology or government administration. Each text possesses its own intellectual and political agendas that further elucidate the complex ambitions of these bilingual projects.

\section{General Lexicons: Translating Words}

Authors first generated Sanskrit-Persian lexicons in the fourteenth century and built upon a long history of intellectuals who crafted monolingual Sanskrit dictionaries particularly to assist poets (Vogel 1979, p. 304). Sanskrit-Persian works were also part of a larger network of philological knowledge that constituted a core component of royal power in premodern India and often intersected with courtly patronage. ${ }^{8}$ While the bilingual lexicons generally present themselves as emerging from the Sanskrit tradition, it is worth noting that Persian dictionaries are known from as early as the eleventh century and were produced actively on the

\footnotetext{
${ }^{6}$ A copy of Kavi Karṇapūra's Samskṛtapārasīkapadaprakāśa survives in a Nepalese script (nepālalipi) (introduction to Saṃskrtapārasīkapadaprakāśa, p. i). Additionally, a manuscript of Krṣnadāsa's Pārasiprakāśa contains a line of Tamil writing on the final folio (ms. Pune Bhandarkar Oriental Research Institute [BORI] 92 of 1907-1915), which suggests it either traveled to Tamil Nadu or was read elsewhere by a Tamil intellectual.

7 On the central place of Amarakośa among Sanskrit lexica, see Vogel (1979, pp. 309-313).

${ }^{8}$ On the relationship of philology and power in Sanskrit, see Pollock (2006, pp. 162-176).
} 
subcontinent from the fourteenth century onwards. ${ }^{9}$ Like their Sanskrit counterparts, Persian lexicons were deeply linked with the negotiation of both literary and royal authority. ${ }^{10}$ In this sense, language analysis offered a potent field for cross-cultural negotiations that was overlaid with the grids of culture and power in both traditions. Indologists have frequently argued that bilingual lexicons were designed as handbooks for learning Persian. ${ }^{11}$ Indeed individual works often claimed to serve a practical purpose, as we shall see. The more fundamental objective embedded these texts, however, was a desire to explore different ways of knowing and representing a cultural and linguistic other.

In 1365, Salakșa composed the first known bilingual lexicon of Sanskrit and Persian, titled Śabdavilāsa (Play of Words, also called Pārasinnamamāāā, Garland of Persian Words). ${ }^{12}$ Salakșa's work precedes all other dated attempts to match Sanskrit and Persian terms by two centuries and thus attests to the relatively early inauguration of this mode of intellectual inquiry in the history of Indo-Islamic power. ${ }^{13}$ Salakșa envisioned his project as participating in a time-honored lexicographic tradition but nonetheless able to speak to the new needs of Sanskrit intellectuals working in increasingly multicultural contexts. Moreover, Śabdavilāsa exhibits several features that persist throughout Sanskrit intellectuals' engagements with the Persian language, including Salakșa's connection with a polyglot court and his scholarly methods.

Salakșa places the production and reception of his work within a courtly milieu in the text's opening lines. He says that he composed Śabdavilāsa under the support of a royal patron named Haribrahma, ruler of Idar (ïlivarana) in northeastern Gujarat, who directed the author to "stretch out this list of names." ${ }^{14}$ Gujarat had deep ties to the Delhi Sultanate and its vision of Turkic power during this period. Salakṣa explicitly identifies his intended audience within a courtly environment where multilingualism was highly valued.

Who among the best of men does not desire fluency in all languages?

Surely he whose wealth is knowledge flourishes in a royal court.

\footnotetext{
9 For recent discussions of premodern and early modern Persian dictionaries, see Kinra (2011, pp. 361-369) and Hakala (2010, pp. 88-90).

${ }^{10}$ Hakala argues that premodern cultures more broadly shared similar approaches to lexicons (2010, pp. 92-93).

11 E.g., Sarma (1996, p. 1). Ernst suggests that such handbooks could still serve a practical function today in analyzing Persian adaptations of Sanskrit texts (2010, p. 361).

12 On the date, see the text's closing verse (Ms. Patan Hemachandra Jnana Mandir 995, fol. 14a and quoted in Shah 1972, p. 32).

13 Scholars have often mistakenly asserted that a similar text directly preceded Salakșa's work, namely Vidyānilaya Kavi's Yavananāmamālā (Garland of Foreign [Persian] Words), allegedly composed in 1364 (Sarma 2002, pp. 84-85; Vogel 1979, p. 380 n. 261.). In fact, a comparison of the available manuscripts reveals that this text is identical with Salakșa's Śabdavilāsa. The phrase vidyānilaya (abode of wisdom) appears in the work as a description of a Gujarati city that was home to Salakșa's patron (Ms. Patan Hemachandra Jnana Mandir 995, fol. 14a and Shah 1972, p. 32).

14 Śabdavilāsa (v. 6 in ms. Patan Hemachandra Jnana Mandir 995 and v. 7 as quoted in Shah 1972, p. 32). Little is known about Haribrahma (also spelled Haribhrama), but he was presumably a member of the Rathod family that controlled Idar during this period (Shah 1972, pp. 33-34).
} 
Those who are well-known in all places and skilled in all śāstras, they are certainly not ill-educated in any tongue. ${ }^{15}$

Here Salakṣa presents proficiency in many languages as an essential skill for poets who seek royal sponsorship and, above all, fame. This perspective stands in stark contrast to Sanskrit texts from the first millennium CE that celebrated expertise in a closed set of languages (Sanskrit and Prakrits) but prohibited learned men from speaking any foreign (mleccha) tongues. ${ }^{16}$ Of course, Indian intellectuals had repeatedly redefined the list of acceptable languages or simply not applied it to certain vernaculars, such as Tamil. Nonetheless, Salakṣa declines to admit his own innovation in respect to Islamicate languages in particular and next names precedents for his project that extend well into India's past.

According to Salakșa, his intellectual predecessors had long cultivated familiarity with Islamicate traditions.

Varāhamihira, who was resplendent like the sun, the best of the Mihiras,

spoke of Arabic astrological signs by foreign names

in order to assist people who knew the Sanskrit terms.

How could a well-educated man not be skilled in any language?

Pratāpa Bhața — a Brahman, best amongst the learned, versed in the best speech—wrote and even spoke Arabic (giram ārabịn). ${ }^{17}$

The identity of Pratāpa Bhaț̣a remains enigmatic, but Varāhamihira authored the sixth-century Brhatsamhitā, a compendium of Sanskrit knowledge that was incidentally translated into Persian on the orders of Firoz Shah between 1351 and 1388. ${ }^{18}$ Citing these individuals as predecessors, Salakșa offers some justification for his seemingly new project regarding Persian, particularly within a tradition that generally favored continuity above brazen novelty. ${ }^{19}$ Salakṣa's claim that Pratāpa Bhatta was able to write Arabic is particularly striking since Śabdavilāsa does not teach the Perso-Arabic script (nor do any of the later lexicons/grammars discussed here). Knowledge of the script was not necessarily a prerequisite for being

\footnotetext{
15 sarvabhāṣāsu kauśalyam ke necchanti narottamāh / yato hi vijñatāsampat prāpyate rājasamsadi //3// sarvadeśaprasiddhā ye sarvaśāstraviśāradāh / na te kasyām hi bhāṣāyām jāyante doṣabhāṣinah //4// (Śabdavilāsa vv. 3-4. Ms. Patan Hemachandra Jnana Mandir 995, fol. 1b; ms. Ahmedabad LD Institute 8311, fol. 1a; and quoted in Shah 1972, p. 31).

16 Plofker discusses several such works (2011, pp. 468-469).

17 ūce varāhamihiro mihirottamaśrīh / sakreyatāurimukhān yavaneśavācā // meșādibhiḥ suviditān janatopakrtyai / kva syān na vāci kuśali khalu viśvadṛśsā //5// sacchrotriyo brahmavidām varenyo varenyavāco 'yam api prapañcah / niścitya caivam giram ārabīn sa pratāpabhaṭo 'likhad apy avocat //6// (Śabdavilāsa vv. 5-6 quoted in Shah 1972, p. 31). Verse 5 is missing in ms. Patan Hemachandra Jnana Mandir 995, fol. 1b and ms. Ahmedabad LD Institute 8311, fol. 1a. In verse 6, read -prapañcah with both manuscripts.

18 On the Bṛhatsaṃitā translation, see Jalali and Ansari (1985, pp. 161-169). It seems likely that Pratāpa Bhața is the same Pratāpa mentioned by Rāghava in his list of predecessors at the beginning of his Nānārthamañjarī (line 7), although his connection to Perso-Islamicate knowledge remains unclear. A Pratāpa is also named in an eighteenth-century lexicon (Patkar 1980, p. 44).

19 On the penchant for continuity in the Sanskrit tradition, see Pollock (1985). McCrea (2011) discusses alamkāasás̄astra as somewhat of an exception.
} 
considered learned in Indo-Persian, ${ }^{20}$ but this claim seems to deepen Salakșa's precedents for promoting fluency in Persian among Sanskrit intellectuals.

Salakșa follows well-established Sanskrit methods for crafting dictionaries while also hinting at shifted emphases. Like earlier lexicographers, he groups terms by subject matter. He primarily offers standard sections, such as chapters on divine beings (suravarga), the earth (bhümivarga), animals (simhāidivarga), and medicine and herbs (aușadhavarga). ${ }^{21}$ Nonetheless, he also indicates an audience familiar with Indo-Persian elite culture when he includes a separate section on horses (aśvavarga). ${ }^{22}$ His courtly context is apparent when the section on royal terms (räjavarga) stretches to become one of the longest of his text.

Salakșa primarily defines commonplace terms, such as the days of the week, the cardinal directions, and everyday words such as water, earth, and city. But at times his Sanskrit-Persian correspondences involve more culturally-specific items and showcase the challenges in trying to equate two distinct traditions. For example, Śabdavilāsa's section on divine beings pairs Islamic and Hindu religious figures. The work posits, "Ibrahim (Abraham) is lotus-born Brahma and Krṣna is called Muhammad... The great lord (Śiva) is Adam, the prophet (paigambar) is Krșna, and the god of death is Azrael."23 In a similar vein, the section on miscellaneous terms (sañkīnavarga) explains that "śruti is called Qur' an (kurāna); kitāb is both smrti and a book (pustaka). A learned man (mu'allim) is a Qur'an-knower (kurānajñah), and a judge $(q \bar{a} z \bar{l})$ is a smārta." ${ }^{, 24}$ We have no direct information regarding what readers of Salakșa's work would have made of such creative pairings and the occasional term that fuses Persian and Sanskrit. But Salakșa claims that the entire Persianate world could be explained within the intellectual universe of Sanskrit. Such rough syncretism was not unprecedented in other instances of trying to negotiate Islamicate knowledge. For example, the eighth-tenth century 'Abbasid translation movement that brought Greek knowledge into Arabic frequently supplanted Greek deities with Allah (Yücesoy 2009, p. 533). ${ }^{25}$ But, whereas this type of replacement sought to absorb one culture within another, Salakșa's equivalences proclaim a certain commensurability between independent systems.

\footnotetext{
${ }^{20}$ For example, the Hindu interpreters at Goa in the first half of the seventeenth century translated texts from Persian but hired Muslims to read out the Perso-Arabic script to them (Flores 2012).

21 For an overview of how Sanskrit lexicons are typically organized, see Vogel (1979).

22 Salakșa divides his lexicon into the following sections (vargas), in order: sura (gods), vāra (time), rāśi (zodiac), bhümi (earth), nagara (cities), nṛ (men), śarīra (body), dhanya (wealth), kanaka (gold), nīra (water), pakși (birds), vana (trees), aușadha (herbs), siṃhādi (animals), aśva (horses), rāja (kings), and sañkīrna (mixed).

23 Ms. Patan Hemachandra Jnana Mandir 995, fol. 1b and ms. Ahmedabad LD Institute 8311, fol. 1a.

24 kurāṇam śrutisaṃjñạ ca katebaḥ smritipustakau / muālimah kurānajñah kājī smārttaś ca kathyate // (Śabdavilāsa, ms. Patan Hemachandra Jnana Mandir 995 fol. 10a and ms. Ahmedabad LD Institute 8311, fol. 7b).

25 South Asia also offers its own precedents of such equivalences (e.g., the Rabatak inscription).
} 
The reception history of Śabdavilāsa remains unclear, but all extant copies of the text that I have identified to date are held in Jain archives in Gujarat. ${ }^{26}$ This geographical circulation accords well with Salakșa's vision that his text would best serve those operating in multilingual milieus, because Gujarat was a major contact zone for encounters across cultural traditions and was often under Islamicate rule from the fourteenth century onwards. ${ }^{27}$ In terms of religious communities, Jains from western India were frequently at the forefront of forging relations with Islamic kingdoms. Several later bilingual lexicons also evinced similar geographical and religious connections. For example, a work titled Tauruṣkināmamālā (Garland of Turkish [Persian] Words) was composed by a Jain sometime before 1649 and survives today in a single known manuscript in Ahmedabad. ${ }^{28}$ Another author also followed Salakșa in crafting an independent bilingual lexicon with strong ties to both Jain communities and Gujarat that is worth discussing in more detail.

Vikramasimha composed his Pārasībhāṣānuśāsana (Analysis of the Persian Language) between the sixteenth and eighteenth centuries. ${ }^{29}$ Vikramasimha names no patron or other information that could narrow the timeframe of his work. But, despite its elusive date, Pārasībhāṣānuśāsana contains several hints of the wider social and intellectual milieus that informed this project. Throughout his text, Vikramasimha offers section colophons in which he refers to himself as maham (great), a title common in Gujarati inscriptions. Moreover, he claims to be a member of the prāgvāța lineage, a kinship community based in Saurāștra, Gujarat, of which Salakșa was also a member. ${ }^{30}$ Last, at the end of his text, Vikramasiṃha proclaims devotion to a Jain leader called Ānandasūri. ${ }^{31}$ While this name is too common to be conclusively identified with a single historical figure, it indicates that Vikramasimha was Jain.

\footnotetext{
${ }^{26}$ There are at least four manuscript copies of Śabdavilāsa extant today in the following collections: LD Institute of Indology in Ahmedabad (2 incomplete copies listed as one, \#8311), Hemachandra Jnana Mandir in Patan (\#995), and Shri Nitivijaya Jaina Pustakalaya in Cambay (this manuscript was copied by a Tapa Gaccha monk and serves as the basis for Shah's 1972 article). Additional copies are reported to exist in two Jain Bhandars in Baroda (Jinaratnakośa, 1:318, listed under Yavananāmamālā).

27 See Sheikh (2010, pp. 5-6 and 67-71).

28 See ms. Ahmedabad LD Institute 8115, fol. $6 \mathrm{~b}$ on date and authorship. Also, see the discussion of this text in Sarma (forthcoming, pp. 10-11).

29 An edition of Pārasībhāṣānuśāsana published in Lahore in 1945 dates the work prior to 1554, but the grounds of this claim remain unclear to me (I have been unable to locate a copy of this edition, but the editor's proposed date of pre-1554 is cited in Balbir 2007, p. 49). Of the manuscripts I have viewed, the only dated one contains two colophons (ms. Koba Acharya Shri Kailasasagarsuri Gyanmandir 21344, fols. $18 \mathrm{~b}$ and 19b). The earlier colophon places the manuscript's copying in 1713 samvat. But this date is crossed out in the manuscript, along with several lines surrounding it, and a subsequent colophon dates the copy to 1875 vikrama samvat and 1740 saka samvat (1818/19 CE). Even if we grant that the first colophon was copied from an earlier manuscript (and not simply a mistake) and thus accurately records the terminus ante quem for Vikramasimha's work, the cryptic mention of samvat in this context could equally refer to the vikrama samvat calendar $(1657 \mathrm{CE})$ or the śaka samvat calendar $(1791 / 2 \mathrm{CE})$.

30 Pārasībhāṣānuśāsana, ms. Koba 21344, fol. 18a and ms. Pune BORI 53 of 1874-1875, fol. 6b. Pingree names several tājika texts authored by individuals from the prāgvāta clan (1997, pp. 81-82).

31 Jain (1940, pp. 119-120); Pārasībhāṣānuśāsana, ms. Koba 21344, fol. 18b and ms. Pune BORI 53 of 1874-1875, fol. $6 \mathrm{~b}$.
} 
Vikramasimha generally mirrors Salakșa in terms of the content of his text but makes a few significant innovations. He offers similarly eye-catching associations of prophets and deities across Hindu and Islamic traditions (e.g., "Ibrahim is Brahma" and "Kṛṣna is Muhammad"). ${ }^{32}$ He also covers a comparable range of vocabulary. But, in addition to having sections on particular topics, he also divides part of his word list according to grammatical items (e.g., nouns, adjectives, etc.). Most notably, Vikramasiṃha brings Persian into his work in a much more dynamic way than Salakșa by giving a full Persian verse and a list of Persian verbs. These two sections demonstrate a growing trend in early modern India, particularly in Gujarat, of experimenting with more radical possibilities of incorporating Persian into the literary and linguistic structures of Sanskrit.

Vikramasimha begins his text with two multilingual verses that instantiate Salakșa's claims about polyglossia and also double as the conventional opening praise to a deity. The first verse esteems Sarasvatī in four lines, the first composed in Sanskrit and next three each in a different Prakrit.

May the Venerable Goddess Sarasvati purify the mind soiled with ignorance.

She is such that on seeing the white lotus of her seat in the volume of waters represented by the brilliance of her radiant form and shining teeth, the swan thinking it to be the lake Mānasa, gladly resolves to take a bath in it. ${ }^{33}$

The second verse addresses a different deity, namely Allah, and is a series of oddsounding Persian sentences transliterated into Devanagari.

O Lord, you are attached to nothing. All of this is false.

O Rahman, why do you feel compassion for whoever

comes to you with a pure heart, like a servant?

O Allah, salaam to you! Grant me good fortune! ${ }^{34}$

The insertion of a full Persian verse into a Sanskrit text was rare but not unique in the Jain tradition. In fact, this exact verse had previously been attributed to Jinaprabhasūri, a fourteenth century Kharatara Jain monk who visited the court of Muhammad bin Tughluq. ${ }^{35}$ In connection with his ties to the Tughluq court, Jinaprabha is alleged to have composed a few Persian works, the longest of which is

\footnotetext{
32 On religious terms, see Pārasībhāṣānuśāsana, ms. Koba 21344, fol. 1b (compare to Śabdavilāsa, ms. Patan Hemachandra Jnana Mandir 995, fol. 1b). Whether Vikramasimnha knew Salaksa's work remains uncertain.

33 yad gauradyutidehasundararadajyotsnājalaughe mudā / dațthūṇāsaṇaseyapan்kayamiṇam nūṇam saram mānasam // eyam cintiya jhatti esa karade ṇhānammi hamso mudim / sā pakkhāladu bhālad̄̄ bhayavadī jaḍ̣̣̂̄ulittạ̣ maṇam // (Quoted and translated by Jain 1940, p. 121 n. 2).

34 Pārasībhāṣānuśāsana v. 2 (quoted in Jain 1940, pp. 121-122 n. 3; ms. Koba 21344, fol. 1a; ms. Pune BORI 53 of 1874-1875, fol. 1a) In Pārasībhāṣānuśäsana this verse reads (with slight variants between the two manuscripts and printed version): dostī șvanda turā na vāsaya kuyā hāmācunīm drog hasi / cīje āmada pesi to dilusadā vūndī cunīm kīmbarah // tambālā rahamāṇa vāsa-i cirā dostī nisastī irāa / allāllāhi turā salāmu bujiruk rojī marā medihi. Reconstructed into Persian: dūstī khvand turā nah bāshī. kujā hāmā chunīn durūgh hasī chīzì āmad pīsh-i tū dil-i șadā būd̄ chunīn kīmbarah. tan bālā raḥmān bāshī chirā dūstī nishastī irā. alā a'llāh turā salām buzurg rūzì marā mīdih. The commentary defines kīmbarah as karmakaramātre 'pi janah (Jain 1940, p. 122 n. 1; ms. Koba 21344, fol. 19b).

35 Balbir (2007, pp. 43-44). On Kharatara relations with the Tughluqs, see Granoff (1992, pp. 3-40).
} 
eleven verses in praise of Rșabha. ${ }^{36}$ Whether Jinaprabha actually authored the verse quoted above or not, it was available before the sixteenth century, and so Vikramasimha drew upon an existing tradition by incorporating the lines into his text.

The verse, while grammatically Persian, is constructed in the popular Sanskrit meter "tiger's play" (śārdūlavikrị̄ita) and so functions on a basic linguistic level as a Sanskrit composition. This type of poetic fusion renders the verse something in-between Sanskrit and Persian, much like the lexicon it introduces. Moreover, a commentary on the pseudo-Persian verse is appended to the end of several manuscript copies of Vikramasimha's work that glosses each word and also culturally translates the lines. ${ }^{37}$ The commentary begins by imaginatively explaining that rahmān (rahamāṇa in Sanskrit), a Qur' anic name for God meaning "the merciful," comes from the Sanskrit verbal root rah (to abandon) and thus signifies the deity's lack of attachments (vītarāga). In addition to incorporating an Arabic word into Sanskrit, this description also accords nicely with the Jain understanding of Jina, who was often compared to the central deity in various theological systems, as free from passions. Thus, the commentary suggests a cross-cultural śleșa (double-meaning) that invokes Allah and Jina simultaneously. A few later texts and inscriptions authored by Jains from western India employ the name of rahmān without further explanation. ${ }^{38}$ The parallelism asserted here seems to hint that such usages relied on a generally understood, although rarely articulated, syncretic identification.

Vikramasimha also includes a "section on verbs" (kriyāprakaraṇa) that gives a somewhat messy and incomplete overview of the Persian verbal system. Unlike the full grammatical accounts of Persian I discuss below, Vikramasimpha does not explain conjugations, endings, or tenses. He opens with a basic definition of a verb as what is "to be accomplished through verbal relationships." 39 Thereafter, he somewhat inconsistently pairs common actions in both languages. His first of three subsections, titled "present and future" (varttamānabhavisyatau), begins with imperatives (unmarked as such), including "come" (āgaccha in Sanskrit, biyā in Persian) and "speak" (brūhi and bigü). ${ }^{40}$ In this section, he also lists present and future tenses, usually after imperatives but not always. Sometimes he correlates present and future verbs, such as "he goes" in Persian (mīravī, present tense) and "he will go" in Sanskrit (gamisyati, future tense), which perhaps reflects the common Persian usage of the present in the sense of the immediate future. ${ }^{41}$

\footnotetext{
36 See Jain (1950, pp. 47-49) and Balbir (2007, pp. 44-53).

37 Jain (1940, p. 122 n. 1); Pārasībhāṣānuśāsana, ms. Koba 21344, fol. 18b-19b. This commentary is also found in sources that attribute the verse to Jinaprabhasūri.

38 E.g., rahmmān is mentioned in a fifteenth-century Sanskrit inscription in Gujarat cited in Ernst (1992, p. 33) and in Padmasundara's 1569 text on Sanskrit aesthetic theory written for Akbar (Akbarasāhiśrnināradarpaṇa 1.1).

39 Pārasībhāṣānuśāsana, ms. Koba 21344, fol. 13b, v. 1.

40 Pārasībhāṣānuśāsana, ms. Koba 21344, fol. 13b, v. 2.

41 Pārasībhāṣānuśāsana, ms. Koba 21344, fol. 13b, v. 4. Note that mīravī reflects a common spoken pronunciation of mìravad.
} 
In his second verbal subsection, Vikramasimha covers the past tense (atītakāla) in a similar fashion. He again uses basic verbs, such as "grabbed," "went," and "saw," many of which are repeated from the previous section, although not in a parallel order. Moreover, here he frequently matches active past tense Persian verbs (e.g., nivisht, he wrote) with Sanskrit passives (e.g., alikhitam, it was written). ${ }^{42}$ In a sense, this inconsistency stands to reason because Sanskrit favors passive constructions, especially in the past tense, whereas Persian prefers the active. But in order for this section to be intelligible to a reader not already familiar with both languages, some additional explanation would have been required.

The final subsection addresses verbal nouns (kriyāśabda), such as eating (bhakșaṇam and khurdanī) and royal decree (ädeśah and farmān). ${ }^{43}$ Vikramasiṃha furnishes a few comments here that might be described as grammatical explanations, such as that ay and äre are used to get a person's attention and that na and $m a$ are prefixed to verbs to negate them. But he still desists from any systematic discussion. In considering verbs at all Vikramasimha takes a significant step towards explaining Persian in Sanskrit. But his somewhat haphazard treatment leaves one wondering what he hoped to accomplish with such an enigmatic account. It is possible that Vikramasimha follows unacknowledged Persian antecedents in his grammatical presentation, especially in beginning with imperative and future verbs. ${ }^{44}$ This would make sense of his seemingly confusing account, but such direct connections with the Persian tradition remain speculative. Unlike Salakșa, Vikramasimha offers no direct commentary on the intended audience of his work.

Beyond Salakșa and Vikramasiṃha, a few other general Sanskrit-Persian lexicons are extant. In addition to the Taurușkinammamāla mentioned above, another shorter work by the same name survives in the Bhandarkar Oriental Research Institute in Pune and has yet to be examined in any detail. This manuscript begins with the days of the week, constellations, and lunar mansions before moving on to more mundane terms. ${ }^{45} \mathrm{~A}$ few lexicons are said to be found in the royal collection at Jaipur, although these remain unexplored. ${ }^{46}$ Certain Persian words also seeped into early modern lexicons that otherwise proffered only Sanskrit synonyms. For example, two mid-seventeenth-century texts, the latter of which is closely modeled on the former, define $p \bar{a} d s h \bar{a} h$ (king). ${ }^{47}$ Other works from the same period also invoke vernacular terms that are derived from Perso-Arabic vocabulary. ${ }^{48}$

\footnotetext{
42 Pārasībhāṣānuśāsana, ms. Koba 21344, fol. 14b, v.13.

43 Respectively, Pārasībhāṣānuśāsana, ms. Koba 21344, fol. 15b, v. 28 and fol. 15a, v. 21.

44 I am grateful to Walter Hakala for this point.

45 Ms. Pune BORI 50 of 1874-1875.

46 See references in Sarma (1996, p. 8).

47 Mīramīrāsuta defines pādshāh (pātišāha in Sanskrit) in his Asālatiprakāśa (ms. Bodleian Wilson 256b, fol. 2b, line 2). Veṇīdatta, who penned a rehashing of Mīramīrāsuta's work titled Pañcatattvaprakāśa, also defines pātiśāha (ms. Biblioteca Nazionale Orientali 172, fol. 1b, v. 18). Scholars have previously noted certain structural similarities between Asālatiprakāśa and Pañcatattvaprakāśa (Vogel 1979, pp. 363-364). A comparison of these two texts shows that Veṇidatta more frequently than not lifts entire verses verbatim. On Veṇīdatta's text, also see Vogel (2010).

48 E.g., Mathureśa's Śabdaratnāvalī (see Sen's list of words in forward to Śabdaratnāvalī, pp. 3-4).
} 
Moreover, as I note above, nearly all the texts discussed here contain a lexicon. Some works also include full grammars, whereas others more narrowly focus on specialized vocabulary. Nonetheless, like Salakșa and Vikramasiṃha, all later writers employ basic equivalences as the primary mode of trying to negotiate between two distinct cultural worlds.

\section{Full Grammars and the Mughal Court}

Two full Sanskrit grammars of Persian emerged in the late sixteenth and early seventeenth centuries, respectively, and explore the close link between language and power. Vihāri Kṛ̣ṇadāsa composed his Pārasīprakāśa (Light on Persian) on Akbar's orders in the late 1500s, and Kavi Karnapūra crafted his Samskrtapārasīkapadaprakāśa (Light on Sanskrit and Persian Words) at the request of Jahangir in the early 1600s. Both authors worked within the larger polyglot milieu of the central Mughal court that fostered literary production in Sanskrit, Arabic, and Hindi in addition to Persian, the official imperial tongue. ${ }^{49}$ Scholars have only recently begun to give serious attention to the substantial role of Sanskrit in Mughal court life, but projects that involved both Sanskrit and Persian, such as translations, exploded under Akbar. ${ }^{50}$ In many ways it is unsurprising that the most in-depth Sanskrit language analyses of Persian arose within this dynamic environment of cross-cultural exchanges. Moreover, scholars have previously noted that political stability and the associated rise in patronage coincided with several peaks of grammatical production in premodern India, the last of which is the Mughal period. ${ }^{51}$ Additionally, the courts of Akbar and Jahangir took a strong interest in Persian philology, which is most clearly reflected in their successive patronage of the vast linguistic and literary compendium Farhang-i Jahāngīri (Jahangir's Dictionary). ${ }^{52}$ Kṛ̣ṇadāsa and Karṇapūra both participated in the larger movement of ideas and texts across linguistic boundaries during this period. But they developed starkly different visions of the intertwined intellectual and political ambitions of their respective works.

Krṣnadāsa foregrounds his position under imperial Mughal sponsorship throughout his Pârasiprakāśa, which is comprised of two parts: a lexicon and a grammar. Scholars such as Hartmut Scharfe have suggested that he originally conceptualized the sections as two separate, although related works (1977, pp. 196-197). There is

\footnotetext{
49 Thackston (2002) offers an overview of Mughal patronage of Persian as well as other tongues. On Mughal support extended to Hindi authors, see Busch (2010).

50 For recent discussions, see Ernst (2003, pp. 178-187, 2010) and Truschke (2011).

51 E.g., Scharfe (1977, p. 187) and Pollock (2006, pp. 165-176).

52 On the production and content of Farhang-i Jahāngīrī, see Kinra (2011, pp. 369-372). This text became instrumental in Sir William Jones's work on Persian in the eighteenth century (Tavakoli-Targhi 2001, pp. 24-25).
} 
some evidence for this, including that the lexicon and grammar often circulated independently of one another. ${ }^{53}$ But a number of manuscripts pair the texts together so that, even if these were once discrete works, readers early on considered them tightly linked. ${ }^{54}$ He claims direct royal support for both sections of his work and names his courtly location at the beginning of his lexicon, using the king's given name, as "in the assembly of the paramount King Shah Jalaluddin." throughout the grammar portion proclaim the given section is now finished "in Pārasīprakāśa, which was written by Vihāri Krṣnadāsa at the insistence of Glorious Shah Akbar, ruler of the earth." 56

Kṛ̣nadāsa gives no account of how precisely he gained Mughal sponsorship, but his social ties correspond with larger courtly trends. Generous Mughal patronage attracted both Brahmanical and Jain intellectuals who acted as royal astrologers, political negotiators, and resident scholars. ${ }^{57}$ Krṣnadāsa does not elaborate on his courtly activities beyond composing this text but may offer a clue to his identity in the opening praise verse of Pārasīprakāśa. Here he extols Sürya, the sun god, which has prompted scholars to suggest that he may have belonged to the Māga Brahman community that was descended from Persian Zoroastrians. ${ }^{58}$ While this affiliation remains speculative, Krṣnadāsa certainly refers to Akbar's interest in light imagery that resonated with multiple traditions in his opening line. ${ }^{59}$ Akbar was even known to have practiced sun worship by reciting Sanskrit epithets for Sūrya, and so by praising this deity Kṛ̣nadāsa aligns himself with broader cross-cultural practices in the Mughal milieu.

Krṣnadāsa outlines his intellectual objectives in two verses at the beginning of his lexicon.

A collection of some Persian speech is produced by me so that those who understand Sanskrit can enlighten themselves. For those who desire to plunge

\footnotetext{
53 The following manuscripts include only the lexicon portion: Ahmedabad LD Institute 28547 (dated 1654/1655), Bikaner Anup Sanskrit Library 5469 (dated 1676/1677), Bikaner Anup 5471, Calcutta Asiatic Society of Bengal [ASB] 4622, Jodhpur Man Singh Pustak Prakash 626c, and Pune Bharatiya Itihas Samsodh Mandal 29/1758. The following manuscripts include only the grammar portion: Calcutta ASB 4622A, Pune BORI 92 of 1907-1915, and Pune BORI 687 of 1891-1895. Jodhpur Rajasthan Oriental Research Institute [RORI] 28478 and Jodhpur RORI 28486 contain only the ākhyāta and krt sections of the grammar. Note that many of the grammars begin with a brief invocation to Ganeśa and even additional praise verses to ease the rough transition of the text as printed in Pārasīprakāśa of Krṣnadāsa (p. 25). All citations refer to the Varanasi edition published in 1965; Weber also published the lexicon portion of text in 1887.

54 Manuscripts that offer both portions include: Ahmedabad LD Institute 4, Ahmedabad LD Institute 355 (dated 1869/70), Ahmedabad LD Institute 2860, Bikaner Anup 5468, and Bikaner RORI 19965. Also note the manuscripts on which the Varanasi printed edition is based (introduction to Pārasīprakāśa, p. vii).

55 Pārasīprakāśa of Krṣnnadāsa, p. 1, v. 1; note that in Sanskrit jalāladīndra is a play on his name where indra also means lord.

56 E.g., Pārasīprakāśa of Kṛ̣nadāsa, pp. 32, 39, 42, 45, 47, 51, 91, and 97.

57 I offer the most comprehensive account to date of the varied roles that Sanskrit intellectuals adopted in the Mughal milieu in my dissertation (2012, pp. 29-56). Also see Chaudhuri (1942), Patkar (1938a), and Chakravarti (1946).

58 Scharfe (1977, p. 196) and Weber (1887, p. 24 n. 1).

59 On Akbar's interest in light, see Asher (2004).
} 
into the great ocean of the Persian language, Kṛ̣nadāsa makes this life raft of words (nibadhnāti vacahplavam). ${ }^{60}$

Kṛ̣nadāsa thus promises to teach Persian to Sanskrit intellectuals and promotes Sanskrit as the intellectual discourse through which he will present Persian. His lexicon is a list of common words in both languages that follows the style of Amarakośa. Furthermore, at the beginning of his grammar, Kṛ̣nadāsa proclaims that he assumes readers already have a firm grasp of Sanskrit technical vocabulary:

Here there is no collection of [Persian] grammatical terms because the accomplishment of grammatical operations will be expressed through Sanskrit technical terms alone in reference to given things. ${ }^{61}$

Kṛ̣nạadāsa then provides a full linguistic account of Persian by outlining different Sanskrit grammatical formations and slotting in the equivalent Persian construction where appropriate.

Kṛ̣nadāsa generally employs the well-established method of substitution (indicated by use of the genitive) to graft Persian grammar onto Sanskrit, along the way noting the many forms that Sanskrit possesses but Persian lacks. Much of the work is written in terse aphorisms (sütras) that require a solid grounding in Sanskrit grammatical terminology to understand. He draws on both Paninian methods as well as other systems of grammar such as the Kātantra school. ${ }^{62}$ For example, using the common verb "to be," he explains the stem for the simple past as follows: "there is śud (shud) in place of $b h \bar{u}$ for the past tense." 63 For endings, he similarly states: "In the past tense, there is the elision of the third-person singular ending. śud (shud) means abhavat (he was)... $\bar{l}$ is in place of the second person

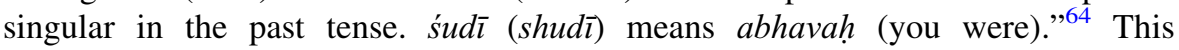
substitution approach may seem opaque today, but it had been used by Sanskrit grammarians for millennia and would have made good sense to intellectuals versed in Sanskrit language analysis. ${ }^{65}$

\footnotetext{
${ }^{60}$ kiyatām pārasīkānām vacasām sañgraho mayā / vidhīyate svavodhārtham saṃkrțārthāvabodhanaih //5// ye vagāhitum icchanti pārasīvāinmahārṇavam / teșām arthe kṛṣnadāso nibadhnāti vacahplavam //6// (Pārasīprakāśa of Kṛ̣nadāsa, pp. 1-2, vv. 5-6).

61 nātra samjiñāsañgrahah //1// kvacid apekșayā saṃskṛtasaṃjñayaiva kāryasiddher vakșyamānatvāt / (Pārasīprakāśa of Kṛ̣ṇadāsa, p. 25).

62 I am indebted to Victor D'Avella for this insight. On the Kātantra system generally, see Pollock (2006, pp. 169-173). On the choice of Kātantra terminology above Paninian terms, see Hahn (2008, pp. 75-85). On Kṛ̣ṇadāsa's grammar, see Ghate's description (1912).

63 bhuvaḥ śuda bhūtārthe //141// (Pārasīprakāśa of Kṛ̣ṇadāsa, p. 54).

64 śudāder dipo lopo vaktavyah //142//śsd abhavad ityarthah /... sipa ìr bhūtārthe //144// dhätoh parasya sipah pratyayasya īr ityādeśo bhavati bhūtārthe / śudī abhava ityarthaḥ / (Pārasīprakāśa of Kṛ̣nadāsa, p. 54).

65 Kahrs (1998, Chap. 5). It is also worth noting that this type of approach is hardly unique to Sanskrit thinkers. Early colonial grammarians pursued a parallel method of understanding Indian languages through the framework of western linguistics (Steadman-Jones 2007). I thank Walter Hakala for the reference.
} 
Nonetheless, the social context of the text prompts us to question whether language instruction was truly Kṛ̣nadāsa's primary goal. ${ }^{66}$ While Indians began learning Persian in substantial numbers during the late sixteenth century, we lack evidence that they typically learned Sanskrit first. On the contrary, scholars have suggested that Indians gained fluency in Persian primarily through the madrasa system of Islamicate education that was reformed during Akbar's reign. ${ }^{67}$ Moreover, while Krṣnadāsa's grammar could have imparted a basic grammatical understanding, it would hardly have cultivated any ability to speak Persian and contains no discussion of pronunciation. Perhaps a teacher was imagined to fill in these gaps, but we possess little evidence of bilingual individuals during this period (beyond Kṛ̣ṇadāsa and Kavi Karṇapūra) that could have fulfilled this role. Such people were certainly unknown in Akbar's court (aside from Krṣnadāsa) because Abū al-Fazl bemoans his inability to find anybody fluent in both tongues to assist with his account of Sanskrit knowledge in the $\bar{A}$ 'in-i Akbari (Akbar's Institutes). ${ }^{68}$ Even during Jahangir's time, we know of only a few individuals capable in both languages. 69

Instead it seems more plausible that Kṛ̣nadāsa sought to construct a politicointellectual account of Persian through a grammatical analysis. Sanskrit possesses an extensive tradition of theorizing speech that stretched back around 2,000 years before Akbar's reign and often involved discourses of knowledge and power. Furthermore, the study of grammar had long provided a central stage for the production and negotiation of authority claims on the subcontinent. As Sheldon Pollock has put it, "power's concern with grammar, and to a comparable degree grammar's concern with power, comprised a constitutive feature of the Sanskrit cosmopolitan order" (2006, p. 176). Kṛ̣nadāsa follows this broad philological tradition in describing Persian, the new language of empire, through the discursive tools of Sanskrit. Thereby he sought to integrate Persian into the Sanskrit thought world and its notions of power. Moreover, in writing under Mughal support, Krṣnadāsa also invoked a second political world that was defined by Indo-Persian imperial culture.

Kṛnnadāsa emphasizes the dual political contexts of his text's production in many ways. For example, his lexicon begins with several conventional verses that cast Akbar within a strong Hindu idiom as an incarnation of Viṣnu. In these verses, Kṛ̣nadāsa evades any semblance of Persianate or Islamicate political norms in favor of eulogizing Akbar as Indian kings had been praised in Sanskrit for centuries.

Since Brahma is described by the Vedas

as changeless and beyond this world,

\footnotetext{
66 Scharfe also questions Krṣnnadāsa's self-articulated goal in Pārasīprakāśs (1977, p. 197).

67 Alam (2004, p. 129).

68 A' '̀n-i Akbarī, 360. Of course the presence of Krṣnadāsa in Akbar's court would seem to contradict this claim. Perhaps Kṛṣnadāsa and Abū al-Fažl were not at court at the same time or the two simply never crossed paths.

69 In addition to Kavi Karṇapūra, Siddhicandra, a Jain monk, claimed to learn Persian at the royal court and subsequently read Persian texts to the king and princes (Bhänucandraganicarita 4.90 and 4.104). Siddhicandra never wrote in Persian, however.
} 
therefore Akbar, great ruler of the earth, was born in order to protect cows and Brahmans.

His virtuous name is celebrated throughout the ocean of śāstras and among smrtis, histories (itihāsa), and the like.

It is established forever in the three worlds, and therefore with his name this work is composed.

It is no surprise that cows were protected by Lord Kṛ̣ṇa, son of Gopāla and the best of the twice-born guarded by the Rāmas, gods of the Brahmans. But it is truly amazing that the lord Viṣnu descended (avatīrna) in a family of foreigners that loves to harm cows and Brahmans.

Akbar protects cows and Brahmans! $!^{70}$

To speak of Akbar as part divine invokes both known Sanskrit royal praises and a specifically Hindu religious context, which is enhanced here by repeated references to cows and Brahmans. Centuries before Mughal rule, Sanskrit poets began treating Islamicate king with established poetic tropes. ${ }^{71}$ Hindi works from the Mughal courts often exhibit a similar tendency to address Mughal figures as if they were no different than classical Indian kings. ${ }^{72}$ Persian translations of Sanskrit works completed in Akbar's court likewise frame the Mughal sovereign as the last of a long line of just Indian rulers. ${ }^{73}$

Mughal culture surfaces more explicitly, however, in the contents of Krṣnadāsa's treatise. In his lexicon, Kṛ̣nadāsa defines certain terms that are pertinent within the Islamicate world, equating the kalima (the Islamic statement of faith) with the mülamantra (the foundational formula) and the khutbah (the Friday sermon read in the name of the reigning king) with the rājyārambhäbhișeka (the initial consecration of kingship). ${ }^{74}$ In the grammar, he mentions specific court practices, such as the sijdah (the full-length prostration instituted by Akbar) and Akbar's predilection for the sun. ${ }^{75} \mathrm{He}$ also includes a number of epithets for people from Central Asia in his explanation of a Persian linguistic construction that signifies a person's origin, such as $k \bar{a} b u l \bar{l}$ and $k h u r \bar{a} \bar{a} \bar{n} \bar{\imath}$. $^{76}$ Most prominently, Kṛ̣nadāsa exemplifies different uses of eight distinct cases (the seven standard Sanskrit cases plus the vocative) with

\footnotetext{
$\overline{70}$ yad brahma vedena vikārahīnam pragīyate sma prakrteh parastāt / tad eșa gobrāhmaṇapālanārtham mahīmahendro 'kavarah prajātah //2// yad asya nāmākhilaśāstrasāgare smrtītihāsādiṣu sādhu viśrutam / gatam trilokīṣu cirasthitị̣ tatas tadākhyayā tantram idạ̣ vitanyate //3// yad gopālasutena krṣnavibhunā gāvas tathā pālitāa / rāmair bhūsuradaivatair dvijavarās trātā na citram hi tat // goviprābhibhavapriye yavanaje vamise 'vatīrno vibhuh / goviprān pratipālayatyakavaro viṣnur vicitram mahat //4// (Pārasīprakāśa of Kṛ̣nadāsa, p. 1, vv. 2-4). Verse 2 has pratīyate instead of pragīyate in the Weber edition (p. 24) and ms. Jodhpur Man Singh Pustak Prakash 626(c) (fol. 1a).

71 See Chattopadhyaya (1998, pp. 28-60).

72 Although see Busch's discussion of some creative uses of Persian words when Braj poets address Islamicate patrons (2011, pp. 90-95).

73 See my discussion of the insertion of Akbar into the Persian translation of the Mahäbhārata (2011, p. 519).

74 Pārasīprakāśa of Kṛ̣nạāāsa, p. 11, v. 125 and p. 15, v. 168, respectively.

75 Pārasīprakāśa of Kṛ̣ṇadāsa, pp. 49 and 43 respectively.

76 Pārasīprakāśa of Kṛ̣nadāsa, pp. 47-48.
} 
phrases repeated in both Sanskrit and Persian that more often than not feature the reigning Mughal king. ${ }^{77}$

Some of the example expressions evoke official Mughal court proceedings. For instance, Krṣnadāsa demonstrates the nominative case with the exclamation: "Long Live Glorious Shah Akbar!"78 Other illustrations showcase a supplicant calling out to the king, such as the vocative case: "O Glorious Shah Jalaluddin, come to my aid in this world and the next!" "This elephant belongs to who? To Akbar!" 80 Typical themes such as service and kingly power are also on display. "I devote myself to the work of Akbar" gives one sense of the dative, and an accusative usage is exemplified by: "The fierce rule of Shah Akbar reduces a forest of enemies to ash." 81

Certain illustrative sentences also indicate how the first Sanskrit grammar of Persian intersected with other cross-cultural endeavors in the imperial court. For example, in one demonstration of the accusative case, Krṣnadāsa celebrates that "Glorious Akbar made the Kali Age into the Era of Truth (satyayuga) by his own justice." 82 The four Indian ages (yugas) were a common trope in Persian retellings of Indian stories both during and after Akbar's reign. ${ }^{83}$ Somehow reimagining the very nature of time signaled the radical otherness of Indic texts to a Mughal audience. Interestingly, Krṣnadāsa adds in the Sanskrit version of this sentence that Akbar is "very ethical" (ativadhārmmikaḥ), which again promotes the image of the Mughal king as a righteous Indian monarch.

Perhaps most interestingly, Kṛ̣ṇadāsa offers the following phrase to exemplify one sense of the dative: "Great Akbar Shah gives titles (khitäb, padavim) to important people." ${ }^{\prime 4}$ This sentence refers to the extensive, although understudied,

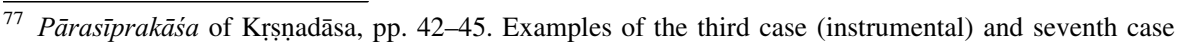
(locative) do not overtly mention Akbar. Note that Kṛ̣nadāsa does not typically give full sentences (beyond "he was," "they were") to exemplify different verb tenses.

78 hajarat śāhe akabara dera be mānad / śrīakabaraśāhaś ciram jīvatu ityarthah (Pārasīprakāśa of Kṛṣnadāsa, p. 42). I have given the Persian here as it appears transliterated into Devanagari.

79 ye hajarati śāhe jallāladīn dastagīra biśū marā dara dīna va duniā / he śrīsāha jallāladīn mama hastāvalambaprado bhava amutreha cetyarthah (Pārasīprakāśa of Kṛ̣nạāāsa, p. 42). Correct the Persian version of the sentence to read hajarati śähi with an izāfah and the verb to read biśū, bishū in Persian (Pārasīvyākaraṇa, ms. Punjab University of Lahore 1225, fol. 4a; also ms. Pune BORI 92 of 1907-1915, fol. 7a for the first correction).

80 ị̀ phīla aj ke as / aj akabaraśāha ityādi / ayam hastī kasyāstīti praśne akabaraśāhasyetyarthạ̣ (Pārasīprakāśa of Kṛ̣ṇadāsa, p. 45).

81 Respectively: barāy kāre akabarśāha sare khud rā nigāh medāram / akabaraśāhakāryyāya śira ātmanaḥ sandhārayāmītyarthaḥ / (Pārasīprakāśa of Kṛ̣ṇadāsa, p. 44) and hukume ātaś śāhe akavara duśmane jañgala rā khākistar mekunad / śāha-akavaraśāsanāgniḥ śatruvanạ̣ bhasmasāt karotītyarthạ (p. 43).

82 śāhajallāladīna aj yadālati khud kaliyuga rā satyayuga kardd / śāhajallāladīno ‘tīvadhārmmikah / śrīmadakabaro nijasunayapratāpāt kaliyugam satyayugam akarod ityarthah (Pārasīprakāśa of Kṛ̣ṇadāsa, p. 43).

83 E.g., Abū al-Faẓl's preface to the Razmnāmah (pp. 21-22); Tārīkh-i Firishtah (1: 6-7); Rawzat al-Ṭăhirīn of Țāhir Muhammad Sabzavārī, ms. Bodleian Elliot 314, (fol. 387b-388a and fol. 421b-422a).

${ }^{84}$ hajarata akabara śāha bā bujurgām khitāba medihad / śrī-akabaraśāho mahadbhyah padavīm dadāti (Pārasiprakāśa of Kṛ̣ṇadāsa, p. 44).
} 
multilingual practice of imperial titling at Akbar's court. Akbar bestowed Sanskrit, Persian, and vernacular titles on intellectuals that operated in any of these three traditions, often across linguistic boundaries. For example, he gave his vizier, Abu al-Fazl, the Sanskrit-derived appellation dalathambana (Pillar of the Army) and honored a few Jain intellectuals with the Persian name khūshfahm (Wiseman). ${ }^{85}$ These titles were central fields for negotiating cultural and political authority at Akbar's court. Kṛ̣nadāsa attests to the strong association of this social practice with the Mughal emperor and its centrality in interactions between members of Sanskrit and Persian cultural milieus more broadly.

Moreover, embedded within Krṣnadāsa's project is something so basic in terms of Mughal power that it is easy to overlook: he penned one of the earliest known grammars of Persian. Persian intellectuals had long devoted sustained attention to explaining the grammatical structure of Arabic. ${ }^{86}$ But we find only a smattering of references to Persian grammars written in Arabic and Turkish beginning in the fourteenth century, and texts are extant only from the mid-sixteenth century. ${ }^{87}$ In underwriting Kṛ̣nadāsa's work, therefore, Akbar sought not only to innovate within the Sanskrit realm but in respect to the Persian one as well. The Mughal relationship with Persian was relatively newly formulated at the time, as Akbar declared Persian the language of empire in 1582. Akbar's ancestors had spoken Turkish, and earlier Indo-Islamic kingdoms typically operated in a combination of Persian and Indian vernaculars. The Mughal decision to promote Persian as an official administrative language had widespread cultural implications. ${ }^{88}$ Kṛ̣ṇadāsa's work ought to be considered part of this larger nexus of Persian language, culture, and power.

Kṛ̣nadāsa's Pārasiprakāśa proved to be quite popular and was widely read. The text is extant today in dozens of manuscript copies across North India, from Gujarat to Bengal, and deep into Maharashtra. ${ }^{89}$ Additionally, the text remained in circulation for centuries, and dated copies continued well into the $1860 \mathrm{~s} .{ }^{90}$ One curious manuscript at the Punjab University of Lahore provides interesting insight into the later history of the grammar. This undated copy is titled Pārasīvyākarana (Grammar of Persian) and has long been confused as a distinct text. ${ }^{91}$ In fact, the

\footnotetext{
$\overline{85}$ On Abū al-Fažl's title, see Bhānucandragaṇicarita 1.77. Akbar fashioned at least two Jain figures as khūshfahm: Nandivijaya (Bhānucandragaṇicarita 4.18 and Vijayapraśastimahākāvya 12.135) and Siddhicandra (Bhānucandraganicarita 4.85; also mentioned in țikā of Kādambarī, p. 483, v. 5 and tịkā of Vasantarājaśākuna, p. 1, v. 9).

${ }^{86}$ A native Persian speaker known as Sībawayh (Sībūya) (fl. late eighth century) authored the foundational text of Arabic grammar, called by one commentator "the Qur'an of grammar" (Versteegh 1997, p. 29). Also see the discussion of continued Iranian participation in the Arabic grammatical tradition in Danner (1975).

87 Storey (1970, pp. 3, $123 \mathrm{ff}$ ). Jeremias suggests some emendations to the standard narrative that Persians did not produce grammars of their own language until the mid-nineteenth century (1993).

88 Alam (2004, Chap. 4).

${ }^{89}$ For a list of manuscripts, see New Catalogus Catalogorum, henceforth NCC (12:38).

90 Ms. Pune Bharatiya Itihas Samsodh Mandal 29/1758 is dated 1857/1858 (fol. 10a) and ms. Ahmedabad LD Institute 355 is dated $1869 / 1870$.

91 See NCC (12:38).
} 
manuscript is an abridged copy of Kṛ̣nadāsa's grammar section that simplifies his presentation of Persian, excising much of the original theoretical grammatical framework. Pārasīvyākarana is too laconic to explain its author's intentions, but it seems reasonable to posit that this adaptation was created by somebody more interested in teaching Persian to those who wished to become part of the Persianate world rather than accounting for the language according to an existing Sanskrit intellectual framework. This shift reinforces my earlier suggestion that Kṛ̣nadāsa prioritizes conceptualizing Persian within Sanskrit analytical discourse to preparing Indians to enter imperial service. Furthermore, the author of Pārasīvyākarana is not the only later intellectual to desire a different formulation of Persian in Sanskrit.

Kavi Karṇapūra composed his treatise on Persian, Saṃskrtapārasīkapadaprakāśa, in the early seventeenth century within the ambit of Mughal patronage. He attests to receiving royal support in an opening verse:

Having taken the blessing of Jahangir, great king of the earth, in the form of a command, Poet Karnapūra composes this Light on Sanskrit and Persian Words. ${ }^{92}$

While Karṇapūra does not saturate his work with references to his imperial context like his predecessor, he volunteers enough biographical information for us to reconstruct the broad outline of his socio-political circumstances. At the beginning of his grammar section, Karṇapūra identifies himself as a "resident of Kāmarūpa" (kāmarūpavāsī, v. 328). He also says:

This composition was written by glorious Karṇapūra, the younger brother of glorious Kavīndra who is an ocean of virtues, the jewel of the karana [lineage], and the king of poets (kavirāja). ${ }^{93}$

Kavīndra was a minister ( $p \bar{a} t r a$ ) of Parikshit Narayan, a local ruler in Assam who was compelled to submit to Mughal authority. ${ }^{94}$ An Assamese text attests that Kavīndra Pātra accompanied Parikshit Narayan to the imperial court at Agra during Jahangir's reign and remained there after the ruler's departure. ${ }^{95}$ Upon Parikshit's death a short while later, Kavindra gained control over areas of Assam at the order of Jahangir and proved instrumental in introducing Mughal influence into the region. ${ }^{96}$

While Karnapūra does not elaborate on how he secured Jahangir's patronage, it seems likely that he entered court through his brother's intervention. Kavīndra was known to bring family members to the Mughal court, such as his son, Kaviśekhara,

\footnotetext{
$\overline{92}$ śrīmajjahānīìramahīmahendraprasādam āsādya nideśarūpam / karotyadah saṃskṛtapārasīkapadaprakāśam kavikarṇapūrah (Samskṛtapārasīkapadaprakāśa v. 2).

93 anujanmanā guṇābdheh karanamaṇeh śrīkavīndrasya / kavirājasya ca vitatā kṛtir eșā śrīkarnapūreṇa (Samskṛtapārasīkapadaprakāśa v. 326).

94 For an overview of this history, see Nath (1989, pp. 96-105), and on Kavīndra, see Vasu (1922, pp. 166-171).

95 Vasu (1922, p. 169). For a list of Sanskrit and local sources on this period of Assamese history, see Nath (1989, pp. 217-226).

96 Vasu (1922, pp. 169-170).
} 
who he introduced to Jahangir and who later became involved in administering Assam. ${ }^{97}$ More generally, there was a longstanding trend stretching back to the early years of Akbar's reign of political embassies both entering and exiting the Mughal milieu while hosting Sanskrit intellectuals. Mahāpātra Krṣṇadāsa, who is best known in Sanskrit circles for composing a treatise on music titled Gìtaprakāśa (Light on Music), joined an official Mughal envoy to Orissa in $1565 .^{98}$ When returning from Orissa in the late 1560s, Mahāpātra brought a second Sanskrit author, Narasimha, within the fold of Akbar's patronage. Also coming from eastern India, Karṇapūra probably entered Jahangir's court in association with his brother's political activities.

Karṇapūra's text is structurally quite similar to Kṛṣnadāsa's work in that it is comprised of discrete lexicon and grammar sections, and the lexicon defines a similar set of vocabulary. ${ }^{99}$ Additionally, Karnapūra may also have conceptualized the two sections of his text as distinct (although connected) works and penned separate praise and introductory verses for each part. ${ }^{100}$ Despite these overarching similarities, Karṇapūra's grammar lacks the technical terminology that pervades Krṣnadāsa's work. Karṇapūra uses far simpler language that relies on basic knowledge of Sanskrit words and case endings rather than formal grammatical discourse. ${ }^{101}$ For example, he illustrates the simple past by listing the five Persian endings according to number and person (third person singular lacks any ending), and then pairs jagāma and raft (he went), raftand and yayuh (they went). ${ }^{102}$

Karṇapūra also articulates the goal of his project differently from Kṛ̣nadāsa and projects his work as useful to Sanskrit and Persian intellectuals alike. In the beginning of his lexicon, he writes:

Knowledge of Persian will come for those who know Sanskrit, knowledge of Sanskrit for those who know Persian, and knowledge of both for those who know both.

Thus this book is to be studied. ${ }^{103}$

\footnotetext{
97 Bhuyan (1934, p. 435). Also see this author's discussion of the text translated here in a series of articles titled "New Lights on Mugul India from Assamese Sources," published in Islamic Culture in 1928.

98 Akbarnāmah of Abū al-Fažl, 2:254-255. Badā'ūn̄̄ also notes Mahāpātra joining this embassy (quoted in Wade 1998, p. 108).

99 Whether the two sections of Kavi Karnapūra's work circulated separately is unclear. We know little about the circulation of Karnapūra's text, primarily because few manuscripts survive. In his lexicon, Karṇapūra also largely follows Amarakośa (Sarma 1986, pp. 190-194).

100 Sampkrtapārasīkapadaprakāśa vv. 1-2 and vv. 326-328.

101 Other scholars have also noted the lucidity of Karṇapūra's exegesis as compared to that of Krṣnadāsa (Sarma 1986, pp. 195-199 and Sarma 2002, p. 85).

102 tadante anda ì eda matra ma viniyojanāt / anyāni pañca rūpāṇi kramāj jñeyāni tadyathā // jagāmārthe tu raphta syāt raphtanda yayur arthake / tvam jagmithārthe raphtī syāt raphted yūyam agacchata (Samskrtapārasīkapadaprakāśa vv. 336-337).

103 saṃskrtoktividi pārasījñatā pārasīvidi ca saṃkṛtajñatā / taddvayāvidi ca taddvayajñatā jāyate 'tra tad adhīyatām idam (Samskrtapārasīkapadaprakāśa v. 3; ms. Calcutta ASB 24327, fol. 1b, v. 3 has some variant readings but the same meaning).
} 
After noting a few details of his text he reiterates, "From knowing one, the other will be understood. From knowing both, both will be understood."104 In these lines, Karnapūra acknowledges the existence of people who know both Sanskrit and Persian, despite the fact that we possess little concrete evidence for significant numbers of bilingual individuals during this period, as I discuss above. But Kavi Karṇapūra expresses a strong interest in producing more such cross-cosmopolitan intellectuals. A few verses later, Karṇapūra reiterates the value of his work for Persian literati who wish to learn Sanskrit:

For yavana cows that are drowning in the mud of lack of treatises, Glorious Karnapūra will pull them up with the rope that is this composition. ${ }^{105}$

Taken with the quotations given above, Karṇapūra seems to elaborate here on his intention to remedy the ignorance of Sanskrit prevalent among Persian literati. However, in the larger context of Jahangir's court, this comment could also potentially refer to the lack of Persian grammars available to date. ${ }^{106}$

A prominent obstacle to the idea that Karnapūra's text could teach Sanskrit is that it is itself written in Sanskrit and so presupposes precisely what it claims to teach. However, three of the four manuscripts copies of Samskrtapārasīkapadaprakāśa that I have identified to date are written in regional, non-Devanagari scripts. ${ }^{107}$ Indo-Persian speakers often picked up vernacular tongues, although whether many could read regional scripts remains uncertain. Alternatively, Persianate "readers" may have listened to such texts more commonly than they read them silently. Regardless of whether they read or heard the work, knowledge of an Indian vernacular combined with Karnapūra's simple language might have made his text accessible to Persian speakers. The Devanagari copy also hints at a heavy Persianate influence (if not necessarily reception) in orienting its pages long ways vertically instead of the more standard horizontal layout of most Sanskrit manuscripts. ${ }^{108}$ But even if teaching Sanskrit to Persian-speakers was part of Karnapūra's ambitions, his project appears to have had only a small impact, as the paucity of manuscripts extant today hint at a relatively limited (if broad in its regional extent) circulation for his work.

After Karṇapūra, no more full Sanskrit grammars of Persian are known. With the works of Kṛ̣ṇadāsa and Karṇapūra as the two complete Sanskrit-Persian grammars, perhaps the most telling contrast between them lies in their respective receptions. As I mention above, Kṛ̣ṇadāsa's text was recopied and even reworked for centuries. In contrast, Karṇapūra's work survives in only a handful of manuscript copies. One

\footnotetext{
$\overline{104}$ ekajñānād aparam dvayam dvayābhijñato jñeyam (Saṃskrtapārasīkapadaprakāśa v. 6b).

105 anibandhapan்kamadhye majjantīnām nibandhasūtreṇa / śrīkarṇapūrakavinā yavanagavām uddhatih kriyate // (Saṃskrtapārasīkapadaprakāśa v. 7; read yavana- as in ms. Calcutta ASB 24327, fol. 1b and printed in Sarma 1986, p. 190).

106 For a discussion of the lack of early grammars in Persian, see Windfuhr (1979, pp. 10-11).

107 Ms. Pune BORI 1502 of 1891-1895 is in Śāradā, ms. Varanasi Sarasvati Bhavan Library 43704 is in Bangla, and the printed edition of the text is based on a manuscript in a Nepalese script (nepālalipi) (introduction to Saṃskrtapārasīkapadaprakāśa, p. i).

108 Ms. Calcutta ASB 24327.
} 
verse from Karṇapūra's text is quoted in a Sanskrit-Persian astronomical lexicon penned by a scholar who worked in Shah Jahan's court, as I discuss below. ${ }^{109}$ But otherwise, we have little evidence of this work having been popular among Sanskrit, Persian, or bilingual intellectuals. Particularly given Kṛ̣nadāsa's emphasis on outlining a meta-view of Persian grammar, this discrepancy in reception likely indicates that Sanskrit thinkers were primarily interested in pursuing a philological knowledge of Persian firmly grounded in their own grammatical tradition. Karnapūra's more basic explanation spoke to few because, regardless of whether Krṣnaadāsa's grammar was ever actually used for language instruction, Sanskrit thinkers desired to understand Persian according to their own intellectual tradition.

Nonetheless, a few later texts demonstrate that aspects of a more straightforward grammatical interest carried on well into the mid-nineteenth century. For example, a work survives in a single-manuscript in the LD Institute of Indology of Ahmedabad that offers "forms of Sanskrit and Persian verbs" (samskrtapārasīdhāturūpāṇi). The work opens with the verb "to be" (shudan, bhü) conjugated in the singular and plural of all three persons in different tenses. ${ }^{110}$ The text then lists around fifteen common verbs (e.g., to see, to eat, to speak) that are conjugated in bilingual pairs. ${ }^{111}$ Further works in this vein may very well surface in other collections, although those known to date remain a far cry from the sophisticated Sanskrit grammars of Persian fueled by Mughal patronage.

\section{Specialized Glossaries in Astrology and Politics}

In the seventeenth century, intellectuals began to apply bilingual lexicographic methods to more focused domains of Persianate knowledge, namely astronomy and government administration. In Sanskrit, both knowledge systems had long been receptive to outside interventions in different ways and housed ongoing exchanges with Perso-Islamic traditions, as I discuss below. Given this, particular lexicons may well have served a practical function of facilitating discussions across cultural lines alongside their intellectual contributions. Astronomy and rulership were also both directly tied with royal courts in early modern South Asia. Accordingly, political interests frequently underlay specialized Persian-Sanskrit lexicons.

Sanskrit astronomy, which also encompassed aspects of astrology and cosmology, was arguably the most porous knowledge system in classical India and, by the Mughal period, had experienced a millennium and a half of transfers from Greek,

\footnotetext{
109 See my analysis of Vedāngarāya's Pārasīprakāśa.

110 Phārasīhāaturūpāvalī, ms. Ahmedabad LD Institute 4644, fol. 1a-2a. For example, the opening line reads: meśavad (mīshavad) bhavati; meśavand (mīshavand) bhavanti prathamapuruṣah (fol. 1a); also see Sarma's transliteration of part of this section (2002, p. 87).

111 The full list of verbs conjugated, in order of their first appearance, is: to be (shudan, bhü), to smell (būyìdan; ghrā), to speak (guftan, brū), to cook (pukhtan, pac), to see (dīdan, driś), to hear (shanìdan, śru), to be (büdan, as), to lick (līisidan, lih), to taste/drink (chashīdan, ācam), to eat (khürdan, khād), to drink ( $\bar{a}$ shāmìdan, pā), to grab (giriftan, grah), to order (farmūdan, ājñ̄a), to find (yāftan, labh), and to escape/ liberate (khalāṣ [used as a verb] and rastan, muc) (Phārasīdhāturūpāvalī, ms. Ahmedabad LD 4644). Some of the later pairings are not conjugated in all persons and numbers.
} 
Arabic, and Persianate traditions. ${ }^{112}$ Greek thought provided the basis for planetary astrology on the subcontinent, and the earliest known translation into Sanskrit was of an astronomical text (Yavanajātaka, c. $150 \mathrm{CE}$ ). ${ }^{113}$ Greek ideas continued to inform Indian astronomy for centuries thereafter, and, writing in the sixth century, Varāhamihira proclaimed:

This science [astronomy] was perfected among the Greeks (yavanas). Thus, despite being barbarians (mlecchas), they are to be worshipped like sages. How much then should a Brahman astronomer be praised? ${ }^{114}$

Even once Islamic ideas began to permeate India near the end of the first millennium, they often introduced features of the Ptolemaic system that had been absorbed from Greek thought.

As Islam became a greater political and social force on the subcontinent from the late twelfth century onwards, its impact on Sanskrit astronomy developed in step. In the thirteenth century, Indian astrologers began producing texts based on adaptations of Islamicate works. These treatises, which often feature extensive Arabic and Persian vocabulary, became known as tājika texts in Sanskrit and continued to be generated into the eighteenth century. ${ }^{115}$ Additionally, date conversions between the Islamic (hijri) and Indian (vikrama or śaka samvat) calendars first arose in the thirteenth century. ${ }^{116}$ In the fourteenth century, Indians started writing Sanskrit manuals about astrolabes, a versatile Hellenic instrument that found its way to India through the Islamic world. The first such work was penned in 1370 by a Jain named Mahendra Sūri who worked in the court of Firuz Shah Tughluq (Sarma 2000b, p. 140).

Continuing this infusion of Perso-Arabic astrology into Sanskrit, the Mughals sponsored their own mixings of Indian and Islamic astrological sciences. Beginning with Akbar, the Mughal kings regularly employed two sets of astronomers who cast royal horoscopes according to Islamic and Indic systems respectively. ${ }^{117}$ This practice drew a series of Brahmans into the court who participated in Mughal social, literary, and material cultures in diverse ways. Several held the official position of jotik rai (jyotișarāja, "lord of astrology") from the late sixteenth until the mid-seventeenth century and were often handsomely rewarded, even receiving their weight in silver and gold. ${ }^{118}$ Some of these astrologers also wrote texts for the Mughals, such as Paramānanda who composed a Sanskrit work on Indian astrology "for the pleasure of Jahangir." 119 One Brahman became a pupil of an Islamic

\footnotetext{
112 For an overview, see Pingree $(1978,1981$, pp. 10-11). Scholars have also pointed out that astronomy tended to be a porous science in many premodern societies (e.g., Goldstein 2009).

113 David Pingree edited and translated this work in 1978.

114 mlecchā hi yavanās teșu samyak śāstram idam sthitam / rṣivatte 'pi pūjyante kiṃ punar daivaviddvijah // (Brihatsamhitā 2.14).

115 See discussion in Pingree (1981, pp. 97-100).

116 Sarma (1990, pp. 434-435).

117 On Akbar's horoscopes cast according to different systems, see Orthmann (2005, pp. 104-113). Moin (2010) discusses the political implications of astronomy in the Mughal court more broadly.

118 Pingree (1997, pp. 84, 92-93) and Sarma (2000a, pp. 368-369).

119 Jahāninīravinodaratnākara v. 10 quoted in Pingree, Census of the Exact Sciences in Sanskrit [CESS], 5A, p. 211.
} 
astrologer at Jahangir's court and crafted a bilingual Sanskrit-Arabic astrolabe (Sarma 2011). Even Sanskrit intellectuals who did not primarily engage with astronomy were drawn into this realm at Mughal demand. Gujarati Jains who visited the imperial court largely in order to gain political concessions report being solicited by Akbar to oversee a ritual that would counteract an astrological curse on his infant granddaughter. ${ }^{120}$

Brahmans outside of the royal court acknowledged the important connection between Sanskrit astrology and Indo-Islamic polities by initiating the production of specialized Sanskrit-Persian lexicons. In 1583, Sūryadāsa, who lived within the Ahmadnagar kingdom in central India, penned a text titled Siddhāntasamhitāsārasamuccaya (Compendium of Essential Points Concerning the Siddhāntas and Samhitās). He devoted one chapter, titled Mlecchamatanirūpaṇa (Investigation into the Views of the Foreigners), to Perso-Arabic ideas regarding astronomy and cosmography. ${ }^{121}$ He first details Islamicate (mleccha) views on the earth's place in the universe, next describes the behavior of celestial bodies, and concludes with twentyseven verses that pair relevant Sanskrit-Persian vocabulary. At the beginning of the lexicon section he specifies the intended courtly reception of this part of his work:

Now I will give the technical terms used in the science of the foreigners (yavana) for things such as the constellations, etc. The meanings of these terms will be useful for royal courts and for astrologers. ${ }^{122}$

He then offers Sanskrit and Persian equivalents for the constellations, zodiac signs, celestial bodies, spherics, and planetary aspects. ${ }^{123}$ Subsequent authors of technically focused lexicons covered more topics than Sūryadāsa but likewise emphasized the courtly uses of such information.

After Sūryadāsa's groundbreaking work, several decades passed before another Sanskrit intellectual produced the first independent bilingual astronomical lexicon. In 1643, Malājit Vedāngarāya, a Brahman from north Gujarat who served as Shah Jahan's jotik rai, authored his Pārasipprakāśa (Light on Persian). ${ }^{124}$ Vedāngarāya links the motivation for his text to the Mughal crown in his opening line:

Having propitiated the goddess, Viṣnu, Śiva, Ganeśa, and the twice-born, the wise Vedāngarāya composes this simple jewel, which explains the differences in Sanskrit and Persian conventions regarding astronomical terms, in order to gain the delight of supreme favor with Glorious Emperor Shah Jahan. ${ }^{125}$

\footnotetext{
${ }^{120}$ Mantrikarmacandravaṃ́āvalīprabandha vv. 359-364; Bhānucandraganicarita 2.140-168. For secondary references, see Andhare (2004, pp. 223-225) and Mitra (1939, p. 1066).

121 On this text, see Minkowski (2004, pp. 329-330).

122 nakșatrapramukhānām saṃjñām brūmo 'tha yavanaśāstroktām / narapatisabhopayogyām upakārārtham ca daivavidām (quoted in Sanskrit in Minkowski 2004, p. 330; translation is my own).

123 Christopher Minkowski is producing an edition of this text and kindly gave me access to this section.

124 For a brief discussion of Vedāngarāya's life and works, see Sarma (2009, 134-135).

125 natvā śrībhuvaneśvarīm hariharau lambodaram ca dvijān/śrīmacchāhajahāṃmahendraparamaprīiprasādāptaye // brūte saṃsḳtapārasīkaracanābhedapradam kautukam / jyotihśāstrapadopayogi saralam vedāngarāyah sudhīh (ms. British Library Sanskrit Additional 14,357b, fol. 1a, v. 1; also printed in CESS 4A, p. 421). Many manuscripts survive of Vedāngarāya's Pārasīprakāśa, and excerpts are printed in Bendrey (1933, Appendixes A and B).
} 
Vedāngarāya was remembered in Sanskrit circles for his affiliation with the Mughal Emperor Shah Jahan, who granted him the name vedāingarāya, meaning "lord of astronomy." 126 As I mention above, Sanskrit intellectuals associated the Mughals with titling practices in general. Here the appellation directly refers to Vedāngarāya's status as a royal astronomer and thus also connects a particular Sanskrit knowledge system to the ruling Perso-Islamic power.

After situating his work in a specific imperial milieu, Vedāngarāya asserts that his text is valuable for those who know Sanskrit, Persian, or both languages. Two things are interesting about this claim. First, Vedāngarāya uses nearly the exact same verse that previously appeared in Kavi Karṇapūra's work composed during Jahangir's reign. ${ }^{127}$ This repetition signals a certain continuity within the tradition of Mughal-sponsored bilingual lexicons, which were likely still in circulation in the royal milieu a few decades later when Vedāngarāya was active. Such correlations, also evident in the title of Vedāngarāya's text, show that Sanskrit intellectuals viewed language analyses of Persian, even when focused on different subfields, as part of the same intellectual project.

Additionally, whereas Sūryadāsa had spoken of foreign (mleccha) views, Vedāngarāya clearly identifies the two systems he is equating according to linguistic categories: Sanskrit (samskrta) and Persian (pārasī). These descriptors are particularly noteworthy given that Vedāngarāya not only pairs specific words in his text but also describes three separate dating systems, none of which we would typically classify according to linguistic terms today. He opens by explaining how to convert between the Indian śaka samvat calendar and the Islamic hijri calendar (complete with its Arabic names for the months). ${ }^{128}$ In addition, he explains the new ilāhī calendar that was instituted under Emperor Akbar. ${ }^{129}$ Here Vedāngarāya appears to conceptualize "Persian" ( $\bar{a} \bar{r} a s \vec{\imath})$ as referring to a wider politico-cultural system that encompassed terms and ideas beyond a strict linguistic framework.

In addition to his discussion of calendars, Vedāngarāya also offers a variety of astronomical information, including terms for the months, constellations, stars, planets, and numbers. He also defines a series of everyday words, such as city, guest, teacher, student, and flower. ${ }^{130}$ David Pingree has noted that his vocabulary list is partially covered by another text likely composed during the reign of Jahangir or Shah Jahan, Hayatagrantha (Treatise on Hay'a). ${ }^{131}$ Hayatagrantha is a translation of a fifteenth-century Persian text produced for the Ottoman Sultan

\footnotetext{
126 As S.R. Sarma has pointed out, vedāingarāya is another way of saying jotik rai (2000a, pp. 369-370).

127 saṃskṛtoktividi ca tatpārasim pārasīvidi ca samskṛtajñatā / taddvayaṃvidi ca taddvayajñatā jāyate tu tad adhīyatām idam // (Ms. British Library Sans. Add. 14,357b, fol. 1a, v. 2). Cf. Saṃskṛtapāras̄̄kapadaprakāśs of Karṇapūra v. 3.

128 Ms. British Library Sans. Add. 14,357b, fol. 1a. Also see Sarma (1985a, b, 2009, pp. 137-139).

129 Ms. British Library Sans. Add. 14,357b, fol. 1a-1b. Also see Bendrey (1933, pp. 7-10 and Appendix A) and Sarma (2009, pp. 139-141).

130 Ms. British Library Sans. Add. 14,357b, fol. 17b-18a. See discussion in Sarma (2009, pp. 141-143).

131 Although even Pingree notes that the two works often use different spellings (1996, p. 475), and Sarma further doubts any confirmed connection (2009, pp. 143-144).
} 
titled Risālah dar Hay'a (Treatise on Astronomy). ${ }^{132}$ Hayatagrantha explains numerous Persian astronomical terms in Sanskrit, typically employing full prose sentences rather than the terse synonym pairings characteristic of Sanskrit-Persian lexicons. Nonetheless, such translations attest to the slippery line within the realm of Sanskrit astronomy between lexicons and other sorts of crossover texts.

Vedāngarāya's work was quite well received and exists today in dozens of manuscript copies. ${ }^{133}$ A scholar named Vrajabhūṣaṇa also composed a 104-verse paraphrase of Vedāngarāya's Pārasīprakāśa, which he titled Pārasīprakāśavinoda (Play of the Light on Persian), in 1659. ${ }^{134}$ Vrajabhūṣaṇa's text did not circulate as widely as its source, but it is nonetheless found in many collections. ${ }^{135}$ Last, at least one further technical astronomical lexicon is known: Jāniprayāga's Pārasīprakāśa, the first chapter of which is available in a single incomplete manuscript. ${ }^{136}$ Nearly everything about this work remains elusive, including its date, the identities of its author and patron, and the majority of the text. But Jāniprayāga continues the strong affiliation of Sanskrit-Persian astronomical lexicons with Islamicate courts and dedicates his work to "Glorious Mirza Sultan, the best son of Bhuya Salatin (Sultan?) Khan."137 Jāniprayāga covers zodiac signs, months, planets, and date conversion in the first chapter, which is the only portion of the text known to survive. This work does not appear to have shared in the popularity of Vedāngarāya's treatise but nonetheless confirms the vibrancy of this subgenre of bilingual dictionaries.

Despite the proliferation of specialized bilingual lexicons and mixed astronomical ideas more broadly, some Sanskrit astronomers remained opposed to incorporating Perso-Arabic ideas. For example, in 1639, Nityānanda completed a text titled Sarvasiddhāntarāja (King of All Siddhāntas) that David Pingree has characterized as "an elaborate apology for using Muslim astronomy" (2003b, p. 270). Nityānanda had previously translated a Persian horoscope of Shah Jahan into Sanskrit at the request of Asaf Khan, the royal vizier. In Sarvasiddhāntarāja, Nityānanda seeks to justify this act by effacing his connection with anything that originated outside of the Sanskrit thought world. He identifies the source for Shah Jahan's horoscope as Sūrya. He also avoids using Persian or Arabic terms in explaining his calculations, preferring instead often-clumsy Sanskrit explanations. ${ }^{138}$ Several authors followed Nityānanda in minimizing Persian vocabulary, such as Mathurānātha who wrote in the late eighteenth century. ${ }^{139}$ At the same time, the eighteenth-century Jaipur court of Sawai Jai Singh supported translations of Persian, Arabic, and European astronomical

\footnotetext{
132 Pingree (1978, pp. 326-327, 1996, p. 475). The Persian text was itself a translation of an earlier Arabic work by the same author, 'Alā' al-Dīn al-Qūshjī (Saliba 1998, p. 142 n. 45).

133 Based on CESS, Sarma counts 45 copies (2009, p. 136). Also see NCC (12:38) and CESS (A5, p. 755b).

134 Sarma (2009, pp. 144-146).

135 NCC (12:38).

136 Ms. Allahabad Municipal Museum 432/106. Jāniprayāga's Pārasīprakāśa has previously been listed as by Kṛtavīryātmaja, which is incorrect (NCC 12:38; nonetheless the opening verse of the text remains enigmatic).

137 Ms. Allahabad Municipal Museum 432/106, fol. 1b, v.1. The identity of this ruler remains unclear to me.

138 See descriptions of Sarvasiddhāntarāja in Pingree (2003b, 1996, pp. 476-480).

139 Pingree (1996, pp. 480-481). More generally, see discussion in Plofker (2009, pp. 277-278).
} 
materials into Sanskrit in order to infuse the science with new life. ${ }^{140}$ These widely varying attitudes attest that, even within a knowledge system long open to outsiders, active engagement with Persianate thought was a meaningful choice with intellectual and cultural consequences.

The science of rulership was less openly welcoming of external influences than astronomy, but nonetheless a few texts arose in the seventeenth and eighteenth centuries that present lexicons of administrative terms. Unlike bilingual astronomical texts, which sought to build upon a long history of cross-cultural contacts, these works generally had a more subversive cultural agenda. Islamicate kings brought with them distinctive idioms of rulership that had become part of a wider Indian cultural discourse by at least the fifteenth century. For example, Phillip Wagoner (1996) has demonstrated how the Vijayanagara kings used Islamicate dress and even titles such as "sultan" in order to claim a particular type of sovereignty. Additionally, Persian had become common as a literary and administrative language well beyond the confines of Islamicate courts. Select regional rulers also defined themselves in opposition to the broad spread of Islamicate culture, such as the kings of Mewar who resisted marrying their daughters to the Mughal emperors as a way to set themselves apart from other Rajput kingdoms. ${ }^{141}$ Beginning in the late seventeenth century, Sanskrit intellectuals carved out another approach that sought to appropriate and thereby supplant linguistic expressions of power within a Mughal-defined world.

The first and only full text in this vein emerged in the late seventeenth century within the recently forged Maratha Empire. Only a few years into his reign, King Chhatrapati Shivaji, who had defied the Mughals, asked his minister Raghunātha Paṇdita to oversee the production of Rājavyavahārakośa (Lexicon of Royal Institutes). ${ }^{142}$ Rājavyavahārakośa was modeled on traditional Sanskrit lexicons in its form, but the content was dictated by Indo-Persian political culture. The explicit goal of the text was to provide Sanskrit equivalents for commonly used Perso-Arabic administrative terms. The work defines around 1,500 words in all and contains an unusually large section on forts, which were a particular obsession of Shivaji.

Rājavyavahārakośa has been printed several times and discussed more frequently in modern scholarship than perhaps any other lexicon under consideration here. In general, scholars have emphasized that the text attempted to develop a language of rule that did not reference the Persianate culture so strongly associated with the Mughals. The text itself claims:

When the barbarians (mleccha) had been fully eradicated by the crest-jewel of the sun dynasty, a wise man was appointed by Shiva Chhatrapati to write out cultured language, whose ways had been completely desecrated by foreign (yavana) words, for the purpose of royal speech (nrpavyāhārārtham). ${ }^{143}$

\footnotetext{
${ }^{140}$ See Pingree (1987) and Sarma (1998, pp. 75-83). Also see the introduction in Pingree (2003a).

141 Taft (1994, pp. 230-232).

142 On this work, see, most recently, Guha (2011, pp. 60-62). Also see Guha (2004), Tikekar (1971), and Varnekar (1974, pp. 85-86).

143 krte mlecchocchede bhūvi niravaśeșam ravikulāvatamsenātyartham yavanavacanair luptasaraṇim / nrpavyāhārārtham sa tu vibudhabhāṣām vitanitum niyukto 'bhūt vidvān nṛpavaraśivacchatrapatinā // (Rājavyavahārakośa, p. 143, v. 81).
} 
Shivaji made other parallel attempts to define his kingship according to "traditional" Indian norms. For example, in his elaborate coronation ceremony, he emphasized transforming himself, a śüdra by descent, into a kṣatriya. In terms of developing a Sanskrit vocabulary that could describe an early modern Indian kingdom, a few scholars have recently argued that this exercise was not merely pedantic. Walter Hakala notes that the section on epistolary writing is the longest in the text and would have served the needs of an aspiring administrator (2010, p. 87). Sumit Guha has drawn attention to the increase of Sanskrit vocabulary in state letters during the later years of Shivaji's reign (2011, p. 62). In relation to other Sanskrit language analyses of Persian, Rājavyavahārakośa promotes a largely separate project and constitutes more of a break than continuity with earlier bilingual enterprises.

Beyond Rājavyavahārakośa, no other independent Sanskrit-Persian administrative lexicons are known today, but there is at least one subsumed within a larger work. In 1764, Dalapatirāya authored a text titled Yāvanaparipātyanukrama (Index of Persian Methods) at the request of a royal patron that details how to compose various types of official documents. ${ }^{144}$ He devoted his closing section to a Sanskrit-Persian lexicon of words relevant to kingly rule (rājanīti). ${ }^{145}$ Dalapatirāya often defines terms differently than Rajjavyavahārakośa and so does not appear to have relied upon this earlier glossary. Nonetheless, he continues the trend of seeking out Sanskrit terms that were relevant within the increasingly Persianate world of seventeenth- and eighteenthcentury India. ${ }^{146}$

\section{Conclusion: Defining the Other}

Bilingual lexicons and grammars exhibit a wide variety of approaches to the Persianate tradition and attest that language provided a central discourse for crosscultural interests in Sanskrit. Starting in the fourteenth century, basic word lists explored the possibilities and limits of equivalence and also foregrounded the relevance of such projects within political environs. Full grammars arose in the sixteenth and seventeenth centuries. These works developed more elaborate visions for both the intellectual and social impacts of translating the linguistic structure of the Persianate thought world into Sanskrit. From the sixteenth to eighteenth centuries, intellectuals crafted specialized lexicons that participated in the crosscultural and often contested domains of astrology and politics. Taken together, these texts demonstrate that Sanskrit authors over the course of several centuries thought deeply and diversely about the implications of Persian for their intellectual tradition.

Even after this extensive investigation into individual works, the question remains of how to interpret Sanskrit language analyses of Persian as a body of works in their larger social and intellectual contexts. In this vein, it is worth

\footnotetext{
144 Dalapatirāya names his patron as Sawai Mādhavasiṃha, although the identity of this ruler remains contested. For a summary of the debate, see Patkar (1980, p. 162). Also see Gode (1932, pp. 339-340). 145 See list in Patkar (1938b, pp. 154-155). Also see excerpts printed in Bahura (1976, pp. 415-420).

146 I do not include Kșemendra's Lokaprakāśa here, which uses some Persian terms. For a brief description, see Marshall (1967, \#944) and Vogel (1979, pp. 368-369). The work was printed in Srinagar in 1947.
} 
mentioning that, as early as the thirteenth century, Indian intellectuals authored parallel texts in numerous languages that incorporate vernacular tongues. For example, Khāliq Bārī (circa late thirteenth to early fourteenth century) gives terms in Urdu, Persian, and Arabic. ${ }^{147}$ Writers continued to produce such works through the eighteenth century. ${ }^{148}$ Particularly beginning in the seventeenth century, multilingual dictionaries proliferated that include languages such as Marathi and Gujarati paired with Persian and Arabic. ${ }^{149}$ At this time, certain Sanskrit lexicons also began to show a heavy density of vernacular terms. ${ }^{150}$ The relationship between Sanskrit-Persian lexicons and texts that incorporate other tongues remains to be worked out, but early modern intellectuals more broadly tried to make sense of their world through words and language.

In analyzing one set of these vernacular materials, namely lexicons involving Urdu, Walter Hakala proposes that "lexicographic works not only reflect, but themselves shape, the historical realities in which they are produced and applied" (2010, p. 8). Scholars have often invoked the metaphor of reflection when speaking of bilingual dictionaries. For example, Ilan Stavans proclaims that "dictionaries are like mirrors: they are a reflection of the people who produced and consumed them" (2005, p. 57). Writing primarily about the western tradition, Jonathon Green tenders the alternative suggestion that dictionaries change rather than reproduce cultures. He characterizes lexicographers as "playing God" in declaring the laws of language and akin to priests in "revealing truth" (1996, p. 16). Indeed, scholars have long identified grammars as "uniquely central" to the Sanskrit tradition in part because they quickly transitioned from being descriptive to being prescriptive (Bronner 2010, p. 15). Nonetheless, we are largely unable to access the impact of most Sanskrit language analyses of Persian given their limited circulation and our lack of knowledge concerning the reception of the few that did circulate widely, such as Kṛ̣ṇadāsa's Pārasīprakāśa.

Instead of characterizing these texts as descriptive or prescriptive, the framework of translation may offer a more fruitful mode of understanding these cross-cultural projects. In terms of language analysis in particular, Jonathon Green describes the earliest lexicographers, who composed bilingual Sumerian and Akkadian wordlists in the third millennium BCE, as "essentially translators" (1996, p. 13). David Bellos has recently folded this viewpoint into his interpretation of all speech as essentially translation, although he makes the mistake of defining translation here in a narrow practical sense (2011, pp. 94-95). Sanskrit lexicons and grammars of Persian were far more than aids for would-be bilinguals. They attempted to adapt, however messily, the very structures of thought and language from one system into another. In the past few decades, many Indologists have found the concept of translation in a broad sense useful for understanding complex cultural and

\footnotetext{
147 For a discussion of this text, see Hakala (2010, Chap. 4).

148 For example, in 1764, Hīrālāl Kayasth composed a Persian-Hindi glossary titled Pārasīprakāśakośabhāṣa that survives in a unique manuscript in the Sawai Mansingh II Museum and Library in Jaipur (Sarma 1996, p. 8).

149 See texts mentioned in Tikekar (1971, p. 27).

150 Patkar (1980, pp. 41-43).
} 
intellectual processes in Islamicate India. ${ }^{151}$ Sanskrit grammars and lexicons of Persian participated in larger trends of trying to produce meaning across cultural lines. They also poignantly explore the implications of translating entire bodies of knowledge and how bridging cultural boundaries was often a politically and culturally charged task.

Many of the authors of these lexicons and grammars, beginning with Salakșa, emphasize that those who desire to operate within courtly milieus need to learn Persian. But these writers do not directly address the question: did learning Persian mean becoming Persianate? Some felt that they could effectively draw a line between translation and transculturation. For example, Kṛṣnadāsa implicitly admits that there are Persianate ways of conceptualizing grammar in his assertion that he will draw exclusively on the Sanskrit grammatical tradition for his presentation of the Persian language. ${ }^{152}$ But, writing a few centuries later, Raghunātha found the opposite to be true and developed a bilingual lexicon precisely to eclipse the dangerous and pervasive use of Persianate administrative vocabulary. In both cases, Sanskrit intellectuals viewed their attempts to describe Persian as undeniably political and exhibited how defining an outside knowledge system involved navigating the potentially perilous ideas of comparison and equivalence.

Acknowledgments I thank Victor D'Avella, Walter Hakala, and Andrew Ollett for commenting on earlier drafts of this essay, and I am also grateful to Victor for his assistance reading several of the texts discussed here. I am indebted to S.R. Sarma for many fruitful discussions concerning these materials. I acknowledge the following individuals for their help procuring copies of manuscripts: Krista Gulbransen, Jon Keune, Pasha M. Khan, S.R. Sarma, and Steven M. Vose. I gratefully acknowledge the many libraries in India, Pakistan, and the United Kingdom that allowed me access to their manuscript collections. Much of this research was supported by a Fulbright Hays doctoral dissertation research abroad fellowship.

\section{References}

\section{Manuscript Sources}

Asālatiprakāśa of Mīramīrāsuta. Bodleian Library, Oxford, Wilson 256b.

Pañcatattvaprakāśa of Veṇidatta. Biblioteca Nazionale, Rome, Orientali 172. Facsimile printed in The Sanskrit grammar and manuscripts of Father Heinrich Roth S.J. (1620-1668), edited by Arnulf Camps and Jean-Claude Muller. Leiden: Brill, 1988.

Pārasībhāṣānuśāsana of Vikramasiṃha. Acharya Shri Kailasasagarsuri Gyanmandir, Koba, No. 21344. Pārasībhāṣānuśāsana of Vikramasiṃha. Bhandarkar Oriental Research Institute, Pune, No. 53 of 1874-1875.

Pārasīprakāśa of Jāniprayāga. Allahabad Municipal Museum, Allahabad, Sanskrit No. 432/106.

Pārasīprakāśa of Kṛ̣ṇadāsa. Man Singh Pustak Prakash, Jodhpur, No. 626(c).

Pārasīprakāśa of Kṛ̣nadāsa. Bhandarkar Oriental Research Institute, Pune, No. 92 of 1907-1915.

Pārasīprakāśa of Kṛ̣ṇadāsa. Bharatiya Itihas Samsodh Mandal, Pune, No. 29/1758.

Pārasiprakāśa of Vedāngarāya. British Library, London, Sanskrit Additional 14,357b.

Pārasīvyākaraṇa. Punjab University Library, Lahore, Sanskrit 1225.

Phārasìdhāturūpāvalī. LD Institute of Indology, Ahmedabad, No. 4644.

\footnotetext{
151 E.g., see the work of Richard Eaton, Barry Flood, Tony Stewart, and Phillip Wagoner.

152 I am indebted to Andrew Ollett for this point.
} 
Rawżat al-Ṭāhirīn of Țāhir Muḥammad Sabzavārī. Bodleian Library, Oxford, Elliot 314.

Śabdavilāsa of Salakșa. Hemachandra Jnana Mandir, Patan, No. 995.

Śabdavilāsa of Salakșa. LD Institute of Indology, Ahmedabad, No. 8311.

Samskḳtapārasīkapadaprakāśa of Karṇapūra. Asiatic Society of Bengal, Calcutta, No. 24327.

Taurușkināmamālā. LD Institute of Indology, Ahmedabad, No. 8115.

Tauruṣkināmamālā. Bhandarkar Oriental Research Institute, Pune, No. 50 of 1874-1875.

\section{Primary Sources}

A' '̌n-i Akbarī of Abū al-Faznl ibn Mubārak. Edited by Sir Sayyid Ahmad. Aligarh: Sir Sayyid Academy, Aligarh Muslim University, 2005.

Akbarasāhiśrñgāradarpana of Padmasundara. Edited by K. Madhava Krishna Sarma. Bikaner: Anup Sanskrit Library, 1943.

Akbarnāmah of Abū al-Faz̄l ibn Mubārak. Edited by Maulawi Abd-ur-Rahim. 3 vols. Calcutta: Asiatic Society, 1873-1887.

Bhānucandraganicarita of Siddhicandra. Edited by Mohanlal Dalichand Desai. Ahmedabad-Calcutta: Sanchalaka Singhi Jain Granthamala, 1941.

Bṛhatsaṃitā of Varāhamihira. Edited by Krishnachandra Dvivedi (Vol. 1). Varanasi: Sampurnanand Sanskrit University, 1996.

Hayatagrantha. Edited by Vibhuti Bhushan Bhattacarya. Varanasi: Varanaseya Sanskrit Vishvavidyalaya 1967.

Kädambarī of Bānabhațta and his son (Bhușanabhațta) with the commentaries of Bhānuchandra and his disciple Siddhichandra. Edited by Kashinath Pandurang Parab. Bombay: Pandurang Jawaji, 1940.

Mantrikarmacandravaṃśāvalīprabandha of Jayasoma with the commentary of Gunavinaya. Edited by Acharya Muni Jinavijaya. Bombay: Bharatiya Vidya Bhavan, 1980.

Muqaddamah of Abū al-Fažl ibn Mubārak. In Mahābhārata: The oldest and longest Sanskrit epic. Translated by Mir Ghayasuddin Ali Qazvini Known As Naqib Khan (D. 1023 AH), edited by S. M. Reza Jalali Naini and Dr. N. S. Shukla. 4 vols. Tehran: Kitabkhanah-i Tavuri, 1979-1981.

Nānārthamañjarī of Rāghava. Edited by K.V. Krishnamoorthy Sharma. Poona: Deccan College, 1954.

Pārasīprakāśa of Kṛ̣nạāāsa. Edited by Vibhuti Bhushan Bhattacharya. Varanasi: Varanaseya Sanskrit Vishvavidyalaya, 1965.

Rājavyavahārakośa of Raghunātha Paṇitita. Edited by Kashinath N. Sane. In Śivacaritrapradīpa, edited by D.V. Apte and S.M. Divekar. Pune: Bharata Itihasa Samshodhaka Mandala, 1925.

Śabdaratnāvalī of Mathureśa. Edited by Mahindra Mohan Chaudhuri, with a foreword from Sukumar Sen. Calcutta: Asiatic Society, 1970.

Samskrtapārasīkapadaprakāśa of Karṇapūra. Edited by Hariharanath Yogi. Kashi: Goraksatilla Yogapracarini, 1952.

Tārīkh-i Firishtah of Muhammad Qāsim Firishtah. 2 vols. Pune: Dar al-Imarah, 1832.

Vasantarājaśākuna with țīkā of Bhānucandra. Mumbai: Khemraj Sri Krishnadasa Sreshthina, 1987.

Vijayapraśastimahākāvya of Hemavijaya with the commentary of Gunavijaya. Mumbai: Shri Jinashasan Aradhana Trust, 1988.

\section{Secondary Sources}

Alam, M. (2004). The languages of political Islam: India 1200-1800. Chicago: The University of Chicago Press.

Andhare, S. (2004). Imperial Mughal tolerance of Jainism and Jain painting activity in Gujarat. In R. Crill, S. Stronge, \& A. Topsfield (Eds.), Arts of Mughal India: Studies in honour of Robert Skelton (pp. 223-233). Ahmedabad: Mapin.

Asher, C. B. (2004). A ray from the Sun: Mughal ideology and the visual construction of the divine. In M. Kapstein (Ed.), The presence of light: Divine radiance and religious experience (pp. 161-194). Chicago: University of Chicago Press.

Bahura, G. N. (1976). Literary heritage of the rulers of Amber and Jaipur: with an index to the register of manuscripts in the Pothikhana of Jaipur (I. Khasmohor collection). Jaipur: Maharaja Sawai Man Singh II Museum. 
Balbir, N. (2007). A propos des hymnes jaina multilingues (sanskrit, prakrit, persan). In K. Klaus \& J.-U. Hartmann (Eds.), Indica et Tibetica: Festschrift für Michael Hahn (pp. 39-61). Vienna: Working group for Tibetan and Buddhist studies at the University of Vienna.

Bellos, D. (2011). Is that a fish in your ear?: Translation and the meaning of everything. New York: Faber and Faber.

Bendrey, V. S. (1933). Tārīkh-i Ilāhī. Poona: G.B. Nare.

Bhuyan, S. K. (1934). Annals of the Delhi Badshahate. Islamic Culture, 8(3), 425-438.

Bronner, Y. (2010). Extreme poetry: The South Asian movement of simultaneous narration. New York: Columbia University Press.

Busch, A. (2010). Hidden in plain view: Brajbhasha poets at the Mughal Court. Modern Asian Studies, 44 (2), 267-309.

Busch, A. (2011). Poetry of kings: The classical Hindi literature of Mughal India. Oxford: Oxford University Press.

Chakravarti, C. (1946). Muslim patronage to Sanskrit learning. In D. R. Bhandarkar, K. A. N. Sastri, B. M. Barua, B. K. Ghosh \& P. K. Gode (Eds.), B.C. Law Volume Part II (pp. 176-182). Poona: Bhandarkar Oriental Research Institute.

Chattopadhyaya, B. (1998). Representing the other?: Sanskrit sources and the Muslims (eighth to fourteenth century). New Delhi: Manohar.

Chaudhuri, J. B. (1942). Muslim patronage to Sanskritic learning. Calcutta: Pracyavani.

Danner, V. (1975). Arabic literature in Iran. In R. N. Frye (Ed.), The Cambridge history of Iran: The period from the Arab invasion to the Saljuqs (Vol. 4, pp. 566-594). Cambridge: Cambridge University Press.

Ernst, C. W. (1992). Eternal garden: Mysticism, history, and politics at a South Asian Sufi center. Albany: State University of New York Press.

Ernst, C. W. (2003). Muslim studies of Hinduism? A reconsideration of Arabic and Persian translations from Indian languages. Iranian Studies, 36(2), 173-195.

Ernst, C. W. (2010). Fayzi's Illuminationist Interpretation of Vedanta: The Shariq al-ma'rifa. Comparative Studies of South Asia, Africa and the Middle East, 30(3), 356-364.

Flores, J. (2012). How cosmopolitan were the Hindu interpreters of early modern Goa? Paper presented at Cosmopolitanism in the Early Modern World: The Case of South Asia (16th-18th centuries). Paris, France, May 24-25, 2012.

Ghate, V. S. (1912). Persian grammar in Sanskrit. Indian antiquary, 41, 4-7.

Gode, P. K. (1932). Notes on Indian chronology. Annals of the Bhandarkar Oriental Research Institute, 13, 337-340.

Goldstein, B. R. (2009). Astronomy as a "neutral zone": Interreligious cooperation in medieval Spain. Medieval Encounters, 15, 159-174.

Granoff, P. (1992). Jinaprabhasūri and Jinadattasūri: Two studies from the Śvetāmbara Jain Tradition. In P. Granoff \& K. Shinohara (Eds.), Speaking of monks: Religious biography in Asia (pp. 1-96). Oakville, ON: Mosaic Press.

Green, J. (1996). Chasing the Sun: Dictionary-makers and the dictionaries they made. London: Jonathan Cape.

Guha, S. (2004). Transitions and translations: Regional power and vernacular identity in the Dakhan, 1500-1800. Comparative Studies of South Asia, Africa and the Middle East, 24(2), 23-31.

Guha, S. (2011). Bad language and good language: Lexical awareness in the cultural politics of Peninsular India, ca. 1300-1800. In S. Pollock (Ed.), Forms of knowledge in early modern Asia: Explorations in the intellectual history of India and Tibet, 1500-1800 (pp. 49-68). Durham and London: Duke University Press.

Hahn, O. (2008). Eine altindische Syntaxlehre: Devaśarmans Samanvayapradīpa. Aachen: Shaker Verlag.

Hakala, W. N. (2010). Diction and dictionaries: Language, literature, and learning in Persianate South Asia. Philadelphia: University of Pennsylvania.

Jain, B. D. (1940). Pārasībhāṣānuśāsana of Vikramasiṃha. In M. Shafi (Ed.), Woolner commemoration volume (pp. 119-122). Lahore: Mehar Chand Lachhman Das.

Jain, B. D. (1950). The Persian of Jain Hymns. In V. Bandhu (Ed.), Siddhabhāratī, or the Rosary of Indology, Part one (pp. 47-49). Hoshiarpur: V.V.R. Institute, P. \& P. Organization.

Jalali, S. F. A., \& Ansari, S. M. R. (1985). Persian translation of Varāhamihira's Bṛhatsaṃhitā. Studies in History of Medicine and Science, 9(3-4), 161-169.

Jeremias, E. M. (1993). Tradition and innovation in the native grammatical literature of Persian. Histoire Épistémologie Language, 15(2), 51-68. 
Kahrs, E. (1998). Indian semantic Analysis: the Nirvacana Tradition. Cambridge: Cambridge University Press.

Kinra, R. (2011). This noble science: Indo-Persian comparative philology, c. 1000-1800 CE. In Y. Bronner, W. Cox \& L. McCrea (Eds.), South Asian texts in history: Critical engagements with Sheldon Pollock (pp. 359-385). Ann Arbor, MI: Association for Asian Studies.

Marshall, D. N. (1967). Mughals in India: A bibliographical survey (Vol. 1-Manuscripts). Bombay: Asia Publishing House.

McCrea, L. (2011). Standards and practices: Following, making, and breaking the rules of śāstra. In Y. Bronner, W. Cox, \& L. McCrea (Eds.), South Asian texts in history: Critical engagements with Sheldon Pollock (pp. 229-244). Ann Arbor, MI: Association for Asian Studies.

Minkowski, C. (2004). On Sūryadāsa and the invention of bidirectional poetry (vilomakāvya). Journal of the American Oriental Society, 124(2), 325-333.

Mitra, K. (1939). Jain influence at Mughul court. Indian History Congress, 1061-1072.

Moin, A. A. (2010). Islam and the millennium: Sacred Kingship and popular imagination in early modern India and Iran. Ann Arbor, MI: University of Michigan.

Nath, D. (1989). History of the Koch kingdom, c. 1515-1615. Delhi: Mittal Publications.

New Catalogus Catalogorum: an alphabetical register of Sanskrit and allied works and authors. (1949-). Madras: University of Madras.

Nitti-Dolci, L. (1938). Les grammairiens prakrits. Paris: Adrien-Maisonneuve.

Orthmann, E. (2005). Circular motions: Private pleasure and public prognostication in the nativities of the Mughal Emperor Akbar. In G. Oestmann, H. D. Rutkin, \& K. von Stuckrad (Eds.), Horoscopes and public spheres: Essays on the history of astrology (pp. 101-114). Berlin and New York: Walter de Gruyter.

Patkar, M. M. (1938a). Moghul patronage to Sanskrit learning. Poona Orientalist, 3, 164-175.

Patkar, M. M. (1938b). Yāvanaparipāțī-Anukrama or Patrapraśasti. Indian Historical Quarterly, 14, $153-157$.

Patkar, M. M. (1980). History of Sanskrit lexicography. Delhi: Munshiram Manoharlal Publishers.

Pingree, D. (1970-1994). Census of the exact sciences in Sanskrit: Series A. Philadelphia: American Philosophical Society.

Pingree, D. (1978). Islamic astronomy in Sanskrit. Journal for the History of Arabic Science, 2, 315-330.

Pingree, D. (1981). Jyotiḩśāstra: Astral and mathematical literature. Wiesbaden: Otto Harrassowitz.

Pingree, D. (1987). Indian and Islamic astrology at Jayasimha's Court. Annals of the New York Academy of Sciences, 500, 313-328.

Pingree, D. (1996). Indian reception of Muslim versions of Ptolemaic astronomy. In F. J. Ragep, S. P. Ragep, \& S. Livesey (Eds.), Tradition, transmission, transformation: Proceedings of two conferences on pre-modern science held at the University of Oklahoma (pp. 471-485). Leiden: Brill.

Pingree, D. (1997). From Astral Omens to astrology: From Babylon to Bīkāner. Roma: Istituto Italiano Per L'Africa e l'Oriente.

Pingree, D. (2003a). A descriptive catalogue of the Sanskrit astronomical manuscripts preserved at the Maharaja Man Singh II Museum in Jaipur, India. Philadelphia: American Philosophical Society.

Pingree, D. (2003b). The Sarvasiddhāntarāja of Nityānanda. In J. P. Hogendijk \& A. I. Sabra (Eds.), The enterprise of science in Islam: New perspectives (pp. 269-284). Cambridge, MA: MIT Press.

Plofker, K. (2009). Mathematics in India. Princeton and Oxford: Princeton University Press.

Plofker, K. (2011). 'Yavana' and 'Indian': Transmission and foreign identity in the exact sciences. Annals of Science, 68(4), 467-476.

Pollock, S. (1985). The theory of practice and the practice of theory in Indian Intellectual History. Journal of the American Oriental Society, 105(3), 499-519.

Pollock, S. (2001). The death of Sanskrit. Comparative Study of Society and History, 43(2), 392-426.

Pollock, S. (2006). The language of the gods in the world of men: Sanskrit, culture, and power in premodern India. Berkeley, CA: University of California Press.

Saliba, G. (1998). Persian scientists in the Islamic world: Astronomy from Maragha to Samarqand. In R. G. Hovannisian \& G. Sabagh (Eds.), The Persian presence in the Islamic world (pp. 126-146). Cambridge: Cambridge University Press.

Sarma, D. D. (1986). Saṃskṛtapārasīkapadaprakāśa: ek viśleșanātmak paricay. In R. Tripathi (Ed.), Saṃskṛta sāhitya ko Islāma paramparā kā yogadāna (pp. 187-200). Sagara: Sanskrit Parishad.

Sarma, S. R. (1985a). Conversion of a Hijri date to Śaka date. In B. V. Subbarayappa \& K. V. Sarma (Eds.), Indian Astronomy: A source-book (pp. 60-61). Bombay: Nehru Center. 
Sarma, S. R. (1985b). Conversion of a Śaka date to Hijri date. In B. V. Subbarayappa \& K. V. Sarma (Eds.), Indian astronomy: A source-book (p. 60). Bombay: Nehru Center.

Sarma, S. R. (1990). Islamic Calendar and Indian Eras. In G. Kuppuram \& K. Kumudamani (Eds.), History of science and technology in India (Vol. 2, pp. 433-441). Delhi: Sundeep Prakashan.

Sarma, S. R. (1996). Sanskrit manuals for learning Persian. In A. D. Safavi (Ed.), Adab Shenasi (pp. 1-12). Aligarh: Aligarh Muslim University.

Sarma, S. R. (1998). Translation of scientific texts into Sanskrit under Sawai Jai Singh. Sri Venkateswara University Oriental Journal, 41, 67-87.

Sarma, S. R. (2000a). Jyotișarāja at the Mughal Court. In N. Gangadharan, S. A. S. Sarma, \& S. S. R. Sarma (Eds.), Studies on Indian culture, science and literature: Being Prof. K. V. Sarma felicitation volume presented to him on his 81st birthday (pp. 363-371). Chennai: Sree Sarada Education Society Research Centre.

Sarma, S. R. (2000b). Sultān, Sūri and the Astrolabe. Indian Journal of History of Science, 35(2), $129-147$.

Sarma, S. R. (2002). From Yāvanī to Samıkrịtam: Sanskrit writings inspired by Persian works. Studies in the History of Indian Thought, 14, 71-88.

Sarma, S. R. (2009). Persian-Sanskrit lexica and the dissemination of Islamic Astronomy and Astrology in India. In G. Gnoli \& A. Panaino (Eds.), Kayd: Studies in history of mathematics, astronomy and astrology in memory of David Pingree (pp. 129-150). Rome: Istituto Italiano per l'Africa e l'Oriente.

Sarma, S. R. (2011). A bilingual astrolabe from the court of Jahangir. Indian Historical Review, 38(1), 77-117.

Sarma, S. R. (forthcoming). Teach yourself Persian the Sanskrit way: A survey of Sanskrit manuals for learning Persian, AD 1364-1764. Shri Hazari Mull Banthia Felicitation Volume.

Scharfe, H. (1977). Grammatical literature. Wiesbaden: Otto Harrassowitz.

Shah, U. P. (1972). Śabda-vilāsa or Pārasīnāmamālā of Mantrī Salakșa of Gujarat. Vimarśa: A Half-Yearly Research Bulletin on Rashtriya Sanskrit Samsthan, New Delhi, 1(1), 31-36.

Sheikh, S. (2010). Forging a region: Sultans, traders, and pilgrims in Gujarat, 1200-1500. Delhi: Oxford University Press.

Stavans, I. (2005). Dictionary days: A defining passion. Saint Paul, MN: Graywolf Press.

Steadman-Jones, R. (2007). Colonialism and grammatical representation: John Gilchrist and the analysis of the 'Hindustani' language in the late eighteenth and early nineteenth centuries. Oxford and Boston: Blackwell Publishing.

Storey, C. A. (1970). Persian literature: A bio-bibliographical survey (Vol. 3). London: Royal Asiatic Society.

Taft, F. H. (1994). Honor and alliance: Reconsidering Mughal-Rajput marriages. In K. Schomer, J. L. Erdman, D. O. Lodrick, \& L. I. Rudolph (Eds.), The idea of Rajasthan: Explorations in regional identity (Vol. 2, pp. 217-241). New Delhi: Manohar.

Tavakoli-Targhi, M. (2001). Refashioning Iran: Orientalism, occidentalism, and historiography. NewYork: Palgrave.

Thackston, W. M. (2002). Literature. In Z. Ziad (Ed.), The magnificent Mughals (pp. 83-112). Oxford: Oxford University Press.

Tikekar, S. R. (1971). Raja Vyavahara Kosha: A reappraisal. In A. G. Pawar (Ed.), Maratha history seminar (May 28-31, 1970): Papers (pp. 25-29). Kolhapur: Shivaji University.

Truschke, A. (2011). The Mughal Book of War: A Persian translation of the Sanskrit Mahabharata. Comparative Studies of South Asia, Africa and the Middle East, 31(2), 506-520.

Truschke, A. (2012). Cosmopolitan encounters: Sanskrit and Persian at the Mughal Court. New York: Columbia University.

Varnekar, S. B. (1974). Shivaji's patronage to Sanskrit learning. In B. K. Apte (Ed.), Chhatrapati Shivaji coronation tercentenary commemoration volume (pp. 85-91). Bombay: University of Bombay.

Vasu, N. (1922). The social history of Kamarupa (Vol. 2). Calcutta: V. Nagendranath.

Velankar, H. D. (1944). Jinaratnakośa: An alphabetical register of Jain works and authors (Vol. 1). Poona: Bhandarkar Oriental Research Institute.

Versteegh, K. (1997). The Arabic linguistic tradition. London: Routledge.

Vogel, C. (1979). Indian lexicography. Wiesbaden: Harrassowitz.

Vogel, C. (2010). A late supplement to the first chapter of Veṇīatta's Pañcatattvaprakāśa. In E. Franco \& M. Zin (Eds.), From Turfan to Ajanta: Festschrift for Dieter Schlingloff on the occasion of his eightieth birthday (Vol. 2, pp. 999-1009). Bhairahawa: Lumbini International Research Institute. 
Wade, B. C. (1998). Imaging sound: An ethnomusicological study of music, art, and culture in Mughal India. Chicago: University of Chicago Press.

Wagoner, P. (1996). "Sultan among Hindu king": Dress, titles, and the Islamicization of Hindu culture at Vijayanagara. The Journal of Asian Studies, 55(4), 851-880.

Weber, A. (1887). Über den Pārasīprakāça des Krishṇadāsa. In Abhandlungen der Königlichen Akademie der Wissenschaften zu Berlin (pp. 1-121). Berlin: Verlag der Königlichen Akademie der Wissenschaften.

Windfuhr, G. (1979). Persian grammar: History and state of its study. The Hague: Mouton Publishers. Yücesoy, H. (2009). Translation as self-consciousness: Ancient sciences, Antediluvian Wisdom, and the 'Abbāsid Translation Movement'. Journal of World History, 20(4), 523-557. 